\title{
WestVirginiaUniversity
}

THE RESEARCH REPOSITORY @ WVU

Graduate Theses, Dissertations, and Problem Reports

2014

\section{Effects of Culverts on Brook Trout Genetic Diversity}

Darren M. Wood

West Virginia University

Follow this and additional works at: https://researchrepository.wvu.edu/etd

\section{Recommended Citation}

Wood, Darren M., "Effects of Culverts on Brook Trout Genetic Diversity" (2014). Graduate Theses, Dissertations, and Problem Reports. 359.

https://researchrepository.wvu.edu/etd/359

This Thesis is protected by copyright and/or related rights. It has been brought to you by the The Research Repository @ WVU with permission from the rights-holder(s). You are free to use this Thesis in any way that is permitted by the copyright and related rights legislation that applies to your use. For other uses you must obtain permission from the rights-holder(s) directly, unless additional rights are indicated by a Creative Commons license in the record and/ or on the work itself. This Thesis has been accepted for inclusion in WVU Graduate Theses, Dissertations, and Problem Reports collection by an authorized administrator of The Research Repository @ WVU. For more information, please contact researchrepository@mail.wvu.edu. 


\title{
Effects of Culverts on Brook Trout Genetic Diversity
}

\author{
Darren M. Wood
}

\begin{abstract}
A Thesis submitted
to The Davis College of Agriculture, Natural Resources, and Design at West Virginia University
\end{abstract}

in partial fulfillment of the requirements for the degree of

Master of Science in

Wildlife and Fisheries Resources

\author{
Amy B. Welsh, Ph.D., Chair \\ J. Todd Petty, Ph.D. \\ Steve DiFazio, Ph.D. \\ Department of Wildlife and Fisheries Resources
}

Morgantown, West Virginia

2014

Keywords: culverts; brook trout; genetic diversity; movement barrier; genetic assignment; stream restoration; headwater streams; Upper Shavers Fork

Copyright 2014 Darren M. Wood 


\title{
ABSTRACT \\ Effects of Culverts on Brook Trout Genetic Diversity
}

\author{
Darren M. Wood
}

Brook trout (Salvelinus fontinalis) are a species of concern within their native range due to a historical loss of habitat, overfishing, and stocking of non-native salmonids. Road culverts have been recognized as an additional impediment to population persistence as movement between diverse habitat types has been identified as an alternative life-history strategy to maximize spawning and growth. Brook trout were genetically analyzed using a suite of 13 microsatellite loci above 7 culverts with varying levels of passability classified through a physical protocol. While most sites were not found to have losses in genetic diversity, populations above culverts with a high outlet drop were found to have significant population differentiation when compared to streams with passable culverts and streams without culverts. Additionally, restoration of an impassable road culvert on a second order stream (Beaver Creek) occurred in June 2011, potentially reestablishing connectivity between brook trout populations. Genetic assignment to 18 potential source populations identified 24 individuals $(63 \%)$, of which six $(25 \%)$ were found to be from source populations other than Beaver Creek within one year post restoration. The results of this study emphasize the importance of uninterrupted connection between populations and highlight the success of such restoration projects. 


\section{Table of Contents}

Section Page

Chapter 1: Literature Review and Objectives ..............................................................1

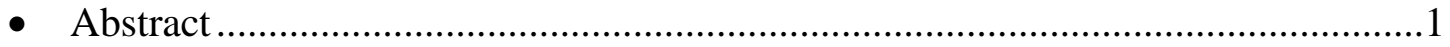

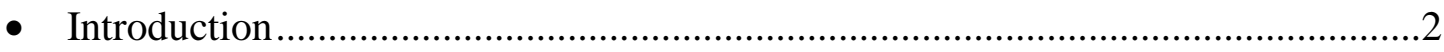

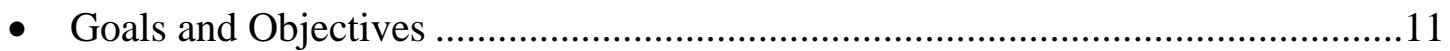

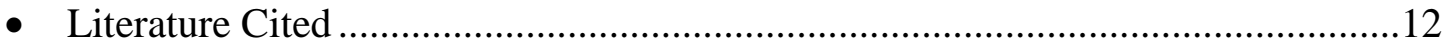

Chapter 2: Effects of Culverts on Brook Trout Genetic Diversity ..................................18

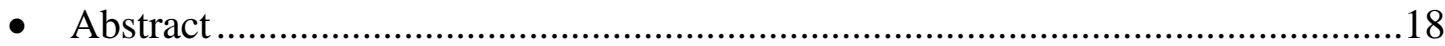

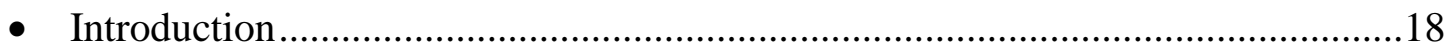

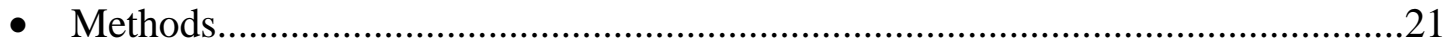

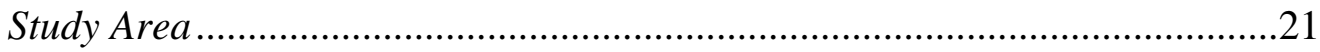

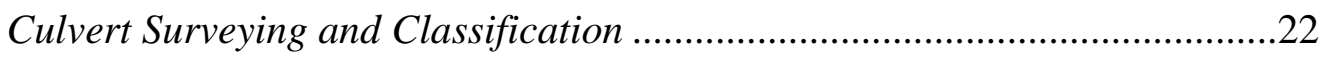

Fish Sampling and Tissue Collection ...................................................22

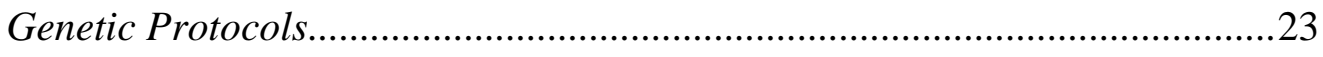

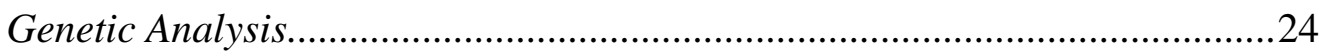

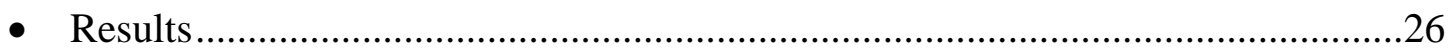

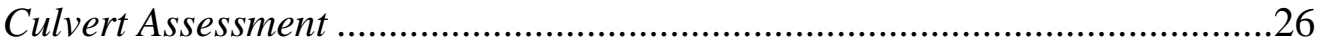

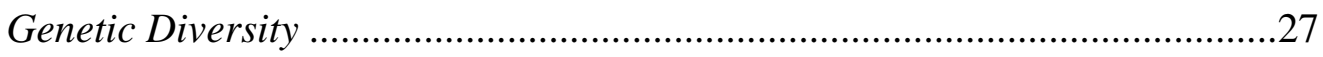

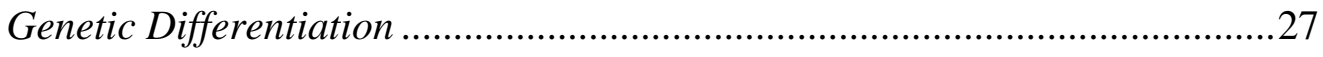

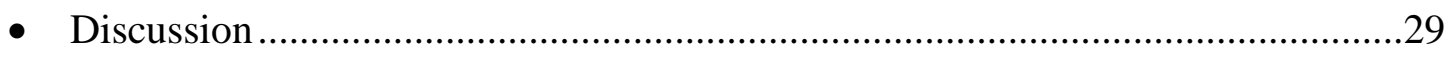

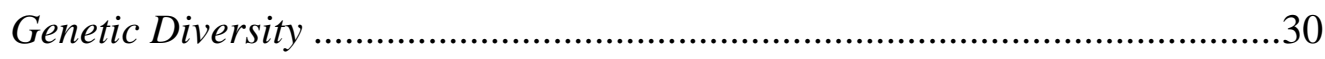

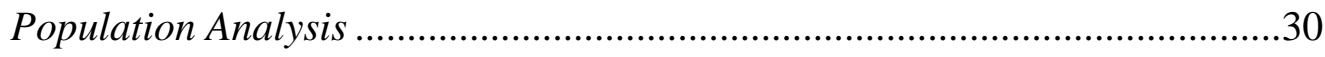




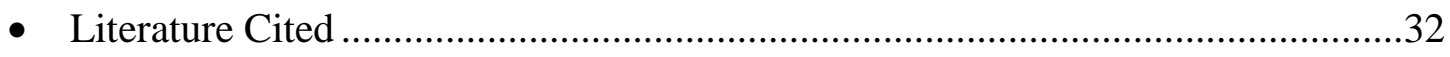

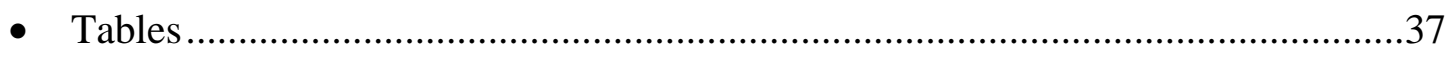

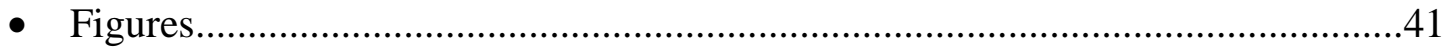

Chapter 3: Identification of Migrants into Beaver Creek after Culvert Restoration

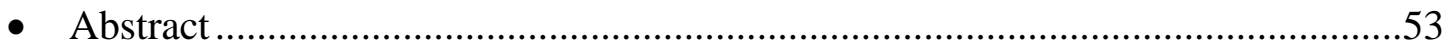

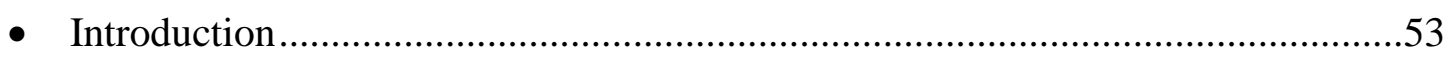

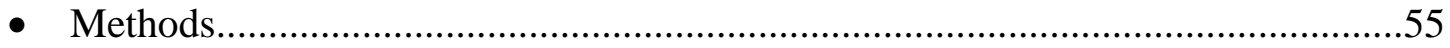

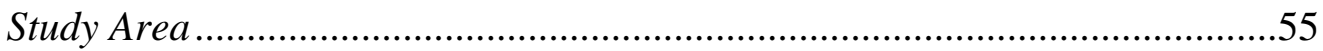

Fish Sampling and Tissue Collection .........................................................56

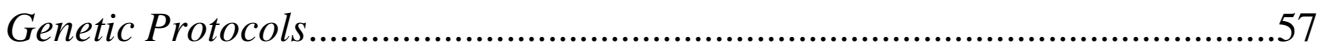

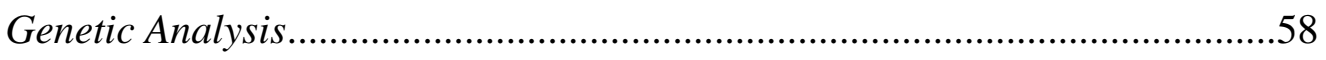

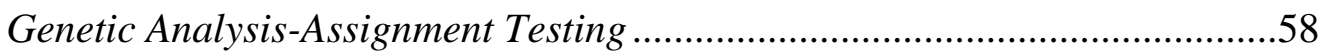

Genetic Analysis-Population Structure ...................................................59

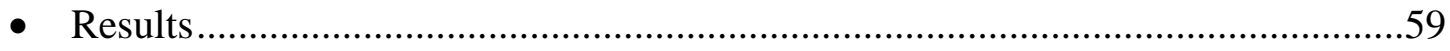

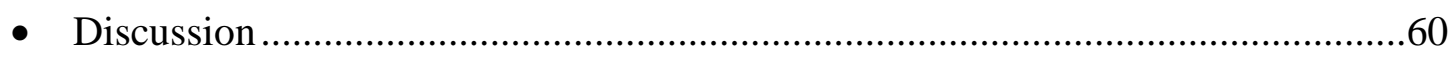

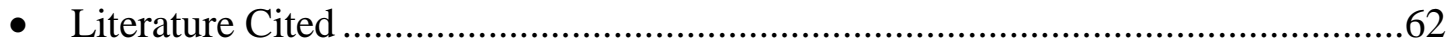

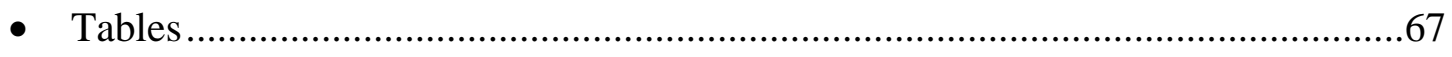

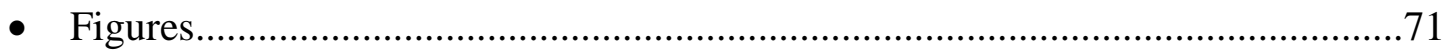




\section{Acknowledgements}

I would like the following people for assistance in the field: Michael Tincher, Catherine "Cat" Artis, Brock Huntsman, Christina Slover as well as the rest of the 2012 Shavers Fork field crew. I would also like to thank field crews and researchers previous to my arrival at West Virginia University for collecting historical tissue samples and conducting research that provided the justification and background information for this study.

I would also like to thank my committee for their continued support, ideas, and advice for my research. I especially like to thank my advisor, Dr. Amy B. Welsh, for the opportunity to work under such an encouraging, patient, and positive individual. Additionally, I would like to thank my advisor at Mansfield University, Dr. Richard Soderberg, for providing me a good example of what it means to live a scholarly life and my research advisor, Dr. John Kirby, for the confidence to pursue graduate school.

Finally, I would like to express my endless gratitude to friends and my family for their continued encouragement; I could have never accomplished anything with the love and support I have received throughout these years. I am truly a blessed person to have surrounded myself with such amazing people throughout these years. 


\title{
Chapter 1
}

\section{Literature Review and Objectives}

\begin{abstract}
Movement can be an important life-history strategy of instream fishes to maximize growth, reproduction, and survival. Population models and several case studies also indicate the significance of movement for regional population persistence. However, movement impediments are sources of reduced species richness, losses of genetic diversity, and native stock extinction. While dams have traditionally been viewed as sources of impediment, road culverts can be another source of movement disturbance. While regulations require uninterrupted migration, culverts can preclude passability through high outlet drops, steep interior slopes, insufficient water, increased water velocities, and culvert length. Assessments of passability have relied on physical protocols, mark and recapture techniques, species composition comparisons, and software modeling. However, noted biases in sampling techniques, differences between modeled and real time conditions and absence of physical assessment verification using biological data leave unanswered questions about culvert passability. Previous use of conservation genetics to verify culvert assessments has been limited; however, brook trout (Salvelinus fontinalis), a highly mobile instream fish provide a model species to verify culvert determinations made through physical assessment protocols.
\end{abstract}




\section{Introduction}

Key foundational studies and several conceptual population theories are the cornerstones of the current understanding of instream fish spatial ecology and the significance of spatiotemporal movements for population persistence. Historically, support for limited movement of instream fishes was founded on Gerking's (1959) "Restricted Movement Paradigm" (RMP; Gowan et al. 1994) which proposed that adult, instream fish exhibit sedentary lifestyles. However, the concept of restricted dispersal has been challenged by several studies which demonstrate that dispersal movements serve as an adaptation to maximize growth, reproduction and survival (Gowan et al. 1994; Petty and Grossman 2004; Utz and Hartman 2006; Hansbarger et al. 2010; Stolarski and Hartman 2010). In addition, Schlosser (1998) found that dispersal movements of creek chubs (Semotilus atromaculatus) from core refugia into adjacent habitats act as an important control for local population dynamics. Core habitats, described as resource-rich environments, act as refugia during unfavorable environmental conditions (Schlosser 1995). Inhabitants of core refugia are "sources" (Pulliam 1998) of excess individuals, as births exceed deaths. Emigrants from source populations into "sink" habitats, where deaths exceed births, is necessary for population persistence in a heterogeneous environment (Pulliam 1988).

While the dynamics of source-sink population regulation justify the importance of spatiotemporal movements in heterogeneous landscapes, Levins' (1969) classical metapopulation theory maintains that a regional population exists as a connected landscape network of spatially discrete local metapopulations. Persistence of the regional population during temporal, localized extinctions requires dispersal and colonization of vacant habitat patches from individuals of neighboring patches (Levins 1969; Hanski et al. 1995; Hanski 1999). For 
populations of in-stream fish subjected to localized extirpation events due to environmental stochastic events (e.g., stream drying, flooding) (Fausch and Bestgen 1997; Morita and Yokota 2002), metapopulation theory emphasizes the importance of dispersal movements into vacant habitats for temporal persistence of the regional population (Fausch 2002).

Patches of spatially isolated populations, as a result of movement barriers, are therefore subjected to a greater severity of population extinction risk (Nagel 1999; Dunham and Rieman 1999; Fagan 2002; Letcher et al. 2007). In a survey of 119 stream basins in the eastern Lahontan basins, Dunham et al. (1997) found 89\% of streams connected to another basin supported populations of Lahontan cutthroat trout. Streams sections isolated by a barrier were only inhabitated 32\% of the time. Additionally, Bertolo et al. (2008) found in a survey of 62 Boreal Shield lakes that isolation and related factors were the greatest predictors of explaining brook trout occurrence.

Loss of connected habitats in aquatic landscapes has traditionally been attributed to the construction of dams. The United States Army Corps of Engineers' (USACE 2013) national inventory of dams currently lists over 87,000 identified dam locations throughout the United States. Although the cumulative total of fragmented channel lengths and total ecological impacts from dams remains unclear, disconnected movement corridors have resulted in delays in juvenile salmon migration and survival (Raymond 1979), reduced American shad (Alosa sapidissima) (Beasley and Hightower 2000), adult striped bass (Marone saxatilis) and salmonid returns (Neraas and Spruell 2001), and salmonid stock extinctions (Raymond 1979; Nehlsen et al. 1991).

In addition to dams, road culverts can be another source of movement disturbance in aquatic landscapes. Culverts are loosely defined as preformed water conveyance structures 
because of their diversity of construction materials and shapes. While commonly applied in loworder streams (Park et al. 2008) due to their cost efficiency (Gibson et al. 2005), culverts could preclude passability due to resulting physical conditions that include high slopes (Poplar-Jeffers et al. 2009), insufficient water depth (Gibson et al. 2005), high outlet drop (Riley 2004; PoplarJeffers et al. 2009; Burford et al. 2009; MacPherson et al. 2012), high water velocities (Belford and Gould 1989; Gibson et al. 2009), and culvert length (Bouska and Paukert 2009, Briggs and Galarwoicz 2013). Consequences of these prohibited movement symptoms have led to isolated stream sections above impassable culverts (Poplar-Jeffers et al. 2009), loss of species richness (Warren and Pardew 1998) and decreased genetic diversity (Wofford et al. 2005; Neville et al. 2009).

Although culvert passability is regulated through the Clean Water Act [section 33, Code of Federal Regulation 323.3 (B)], which states "the design, construction and maintenance of the road crossings shall not disrupt the migration or other movement of those species of aquatic life inhabiting the waterbody" there is currently no federal standard method or protocol for organism passability assessment. Historically, assessments of culvert passability have relied on mark and recapture methods. Warren and Pardew (1998) examined movement of warm-water fish species and compared passage of four different road crossing types including slab, open-box, cylindrical culvert and ford crossings. Utilizing mark-recapture data for 6,113 individuals, they identified significant reductions in mean movement as well as species richness between culvert crossings compared to the open-box, ford crossings, and natural stream reaches (Warren and Pardew 1998). Additionally, Vander Pluym et al. (2008) investigated non-perched road crossings in the Cape Fear River Basin utilizing mark-recapture and reported no differences in species richness for pipe, box, and arch culverts when compared to bridges and stream sections with no crossings. 
Determinations of culvert passability utilizing mark and recapture can be both biased (Gowan and Faush 1996) and inconclusive due to the low number of recaptures (Bouska and Paukert 2009). Vander Pluym et al. (2008) noted only a monthly rate of recapture of $1.91 \%$ to 9.96\%. Other movement studies of instream fishes have also noted recapture rates below $50 \%$. Smithson and Johnston (1999) reported low recapture rates for creek chub Semotilus atromaculatus (22\%), blackspotted topminnow Fundulus olivaceous (18\%), and green sunfish Lepomis cyanellus (30\%). Only one species, longear sunfish Lepomis megalotis, had a recapture rate high enough (>50\%) to make statistical inferences of movement. Additionally, Nakamura et al. (2002) examined movement of Japanese charr (Salvelinus leucomanis), and only reported a recapture rate of 33\%. Though some fish were recaptured at lengths greater than 1000 meters away from their original location, most fish were recaptured in same pool. However due to the low recapture rate, these results can be biased as no conclusions can be made about the $67 \%$ of marked fish not recaptured.

Assessments of culverts comparing population characteristics upstream and downstream of culvert sites have also been used. Nislow et al. (2011) evaluated 86 second and third order stream crossings in Monongahela National Forest and found that species richness and total abundance decreased above culverted sites, but only for those sites that had high outlet drops $(>12 \mathrm{~cm})$. These results are congruent with both the Vander Pluym et al. (2008) and the Warren and Pardew (1998) mark and recapture studies which indicated that limited movement through culverts was caused by high outlet drop. However, Blank et al. (2005) emphasizes upstream and downstream population characteristic comparisons need to occur during temporal periods of high migrations for an accurate population assessment. 
Alternatively, physical assessments of culverts rather than biological experiments are commonly used to classify culvert passability. Common to most physical assessments is a crosssectional survey of the site as well as a longitudinal profile for identification of current stream conditions. Additional parameters may include assessments of stream habitat and culvert condition. Poplar-Jeffers et al. (2009) surveyed and classified 120 West Virginia state owned culverts through the Phase I, Love and Taylor (2003) protocol and determined nearly $70 \%$ of culvert crossings were impassable to all salmonid life stages and that $98 \%$ of surveyed culverts were a barrier to movement to some salmonid life stage. Adopted from the California's Salmonid Stream Habitat Restoration Manual, the Love and Taylor protocol filters culverts into restoration prioritization groupings through passability parameters including channel width versus inlet width, plunge pool depth, outlet drop, interior water depth, culvert slope and potential improvements to current culverts including baffles and weirs.

While it is commonplace for assessments and restoration prioritization to favor aging culverts for study as the physical structure can deteriorate, Gibson et al. (2005) examined newly implemented culvert crossings in the Trans-Labrador Highway using the Department of Fisheries and Oceans guidelines, a physical assessment for passability, and found that $53 \%$ presented barriers to fish movement.

While protocols using physical attributes are efficient for classifying culvert passability for purposes of restoration prioritization, formulating clear conclusions of fish movement without biological data is misguided. Software models have attempted to efficiently connect physical features of culverts along with biological data to classify passability of culverts. Utilizing physical features and hydraulic measurements collected in the field along with species 
specific swim data collected from controlled lab studies, software programs such as FishXing simulate fish movement through culverts at various life stages.

The FishXing software has encountered challengers to the assessment results. Bourne et al. (2011) found that certain flow parameters used in the FishXing software did not accurately estimate the conditions found in the field. Other studies have found potential problems with the FishXing software as well. Poplar-Jeffers et al. (2009) noted that FishXing classified all 120 culverts as impassable, whereas the Phase I, Love and Taylor (2003) protocol classified less than $70 \%$ of the culverts as complete barriers. Additionally, Blank et al. (2005) modeled culverts using FishXing and found that $75-85 \%$ of culverts were impassable at low flows. However, there was no statistical difference in population characteristics upstream and downstream of the culvert, indicating that there could be more movement than previously modeled.

Wofford et al. (2005) examined potential barriers to coastal cutthroat trout (Oncorhynchus clarki clarki) movement as a result of both natural (waterfalls, bedrock cascades) and unnatural barriers (culverts) through professional field assessments and Fish Xing v. 2.2. In addition, Wofford et al. (2005) utilized eight microsatellite loci to validate genetically both physical determinations. Decreases in genetic diversity, measured as observed heterozygosity and allelic richness were associated with increasing number of barriers. Additionally, tributaries without barriers and connected to mainstem habitats were found to have high levels of genetic diversity, and allelic richness. Maintenance of a high level of genetic diversity is of evolutionary importance for species response to variable spatial and temporal environmental conditions (Robinson et al. 1976; Powers et al. 1986; Snyder and Dingle 1989; Nilsson 1992). 
Additionally, Knaepkens et al. (2004) evaluated a culvert as a potential bullhead catfish (Cottus gobio) migration barrier using six microsatellite loci and found congruency between the computer simulation and genetic analysis. While genetics has emerged as a powerful tool for conservation and species management (Schwartz et al. 2006) through its ability to identify finescale population structures (Angers et al. 2005; Hudy et al. 2010; Kanno et al. 2011), verification of culvert assessments at a regional scale requires a highly mobile, instream fish to detect population differentiation caused by impassable culverts.

Brook trout (Salvelinus fontinalis) have been a focus for species' management due to historic reductions of their native range (Hudy et al. 2008) caused by an aggregate of multiple inhibitors including stocking of non-native salmonids (Larson and Moore 1985, Marschall and Crowder 1996), exposure to degraded water quality (Mount et al. 1988, Marschall and Crowder 1996) particularly from acid precipitation in the central Appalachian Mountains (Wigington et al. 1996), and loss of core forest habitat (Hudy et al. 2008).

Research examining the spatial and temporal movements of brook trout has provided an increased understanding of the dynamic nature of the species. While Hudy et al. (2010), utilizing a suite of eight microsatellite loci to create a pedigree reconstruction analysis, found limited dispersal of four month post emergent (age-0) brook trout, other studies (Rogers and Curry 2004; Stolarski and Hartman 2004; Petty et al. 2005; Utz and Hartman 2006; Hansbarger et al. 2010) have indicated that adult brook trout use dispersal to find suitable habitat for spawning and foraging to maximize both growth and reproduction. Although consumption peaks during the spring months (Utz and Hartman 2006), Petty et al. $(2005,2012)$ found that large-adult brook trout move into larger main stem habitats with open canopies during the summer months where aquatic macroinvertebrate density, particularly chironomids and grazers is high (Sotiropolous et 
al. 2006; Nislow and Lowe 2006) and large prey abundance is significantly more than headwater streams (Bopp 2002). The highest dry, protein, and fat weights occur during the early summer months as a result of the increased aquatic invertebrates abundance (Webster and Hartman 2007), but decreased as the season continues as small prey abundance decreases with season (Allan 1981). Daily movement of brook trout inhabiting the larger, mainstem portions was found to be an order of magnitude higher than those observed in tributaries (Petty et al. 2005, 2012) with selection of microhabitats in the main stem near tributaries and deep pools (Petty et al. 2012; Sotiropoulos et al. 2006), likely as a mode to provide thermoregulation during warm summer months (Petty et al. 2012). Survival of brook trout is significantly reduced during increased summer temperatures (Xu et al. 2010) as Martin and Petty (2009) observed that the maximum daily temperature brook trout were found in was $21^{\circ} \mathrm{C}$, underscoring the importance of future conservation efforts to protect cold water refugia (Petty et al. 2012).

Brook trout movement in the mainstem is reduced significantly during the fall (Petty et al. 2012) as trout return to spawn in smaller (basin area $<3 \mathrm{~km}^{2}$ ), high alkalinity (> $10 \mathrm{mg}$ $\mathrm{CaCO}_{3} / \mathrm{L}$ ) headwater streams (Petty et al. 2005). Spawning cues are consistent with a decline in water temperature and increased rainfall (Blanchfield and Ridgway 1997). Petty et al. (2005) found that redd sites were consistently identified with gravel substrates and found in tail sections of pools or the heads of low-gradient riffles. Additionally, headwater streams are a source of groundwater upwelling, providing consistent flow and temperature (Blanchfield and Ridgway 1997). Although maturity occurs at age two for brook trout, as female body size increases, multiple redd sites are often constructed (Blanchfield and Ridgeway 1997); however, lipid reserves decrease twice as fast for larger, reproductive females over winter (Hutchings et al. 1999). 
Accessing headwater streams for spawning, particularly for streams in the central Appalachian Mountains, requires the ability to navigate through steep slopes and waterfalls caused by boulders and large woody debris. For purposes of studying movement through culverts, it is dually important to understand these movement abilities as culverts are prone to outlet hang (Riley 2004; Poplar-Jeffers et al. 2009; Burford et al. 2009; MacPherson et al. 2012) and steep slopes (Poplar-Jeffers et al. 2009). In a controlled laboratory study, Kondratieff and Myrick (2006) evaluated jumping performance of brook trout by using adjustable waterfall devices and found that larger-size (> $200 \mathrm{~mm}$ ) brook trout were capable of jumping $73.5 \mathrm{~cm}$, and brook trout between 100-150 mm were capable of jumping $43.5 \mathrm{~cm}$ waterfalls with plunge pools $>40 \mathrm{~cm}$. Additionally, plunge pools $<10 \mathrm{~cm}$ prevented all brook trout from jumping waterfalls > $43.5 \mathrm{~cm}$

While evaluation of jumping performance in a controlled setting provides baseline data, movements of brook trout in natural settings have been noted that exceed those found in the Kondratieff and Myrick (2006) study. Adams et al. (2000) found that when brook trout were immigrating into previously eradicated stream sections in Idaho, they were capable of ascending $1.2 \mathrm{~m}$-high waterfalls. Furthermore, they accessed slopes of $13 \%$ for greater than $67 \mathrm{~m}$.

Movements of eastern populations of brook trout have been previously documented to access slopes between 8\%-18\% in the Great Smokey Mountains National Park (Larson and Moore 1985). 


\section{Goals and Objectives}

The first goal of this study is to determine if varying levels of culvert passability (determined through physical assessment of the culvert) affects the genetic diversity of brook trout (Salvelinus fontinalis). The second goal of this project is to see if passability has improved after replacement of an impassable culvert at Beaver Creek.

To achieve the first goal, the first objective is to determine if genetic diversity decreases with the presence of culverts that are purportedly impassable. The second objective is to verify if purportedly impassable culverts result in genetic isolation of the upstream population.

In order to achieve the second goal, the objective is to determine if any individuals captured in Beaver Creek following culvert replacement genetically assign to other tributaries of the upper Shavers Fork indicating passability. 


\section{Literature Cited}

Adams, S. B., C. A. Frissell, and B. E. Rieman. 2000. Movements of nonnative brook trout in relation to stream channel slope. Transactions of the American Fisheries Society 129:623-638.

Allan, J. D. 1981. Determinants of diet of brook trout (Salvelinus fontinalis) in a mountain stream. Canadian Journal of Fisheries and Aquatic Sciences 38: 184-192.

Angers, B., L. Bernatchez, A. Angers, and L. Desgroseillers. 1995. Specific microsatellite loci for brook charr reveal strong population subdivision on a microgeographic scale. Journal of Fish Biology 47: 177-185.

Beasley, C.A., and J.E. Hightower. 2000. Effects of a low-head dam on the distribution and characteristics of spawning habitat used by striped bass and American shad. Transactions of the American Fisheries Society 129: 1316-1330.

Belford, D. A., and W. R. Gould. 1989. An evaluation of trout passage through six highway culverts in Montana. North American Journal of Fisheries Management 9:437-445.

Bertolo, A., P. Morgan, and M. Plante. 2008. Linking the occurrence of brook trout with isolation and extinction in small Boreal Shield lakes. Freshwater Biology 53: 304-321.

Blanchfield, P. J., and M. S. Ridgeway. 1997. Reproductive timing and use of redd sites by lakespawning brook trout (Salvelinus fontinalis). Canadian Journal of Fisheries and Aquatic Sciences 54: 747-756.

Blank, M., J. Cahoon, D. Burford, T. McMahon, and O. Stein. 2005. Studies of fish passage though culverts in Montana. Conference proceedings of the 2005 international conference on ecology and transportation. PP. 647-661.

Bopp, J. 2002. The combined effects of water chemistry, canopy cover, and basin area on benthic macroinvertebrates along a central Appalachian stream continuum. Master's thesis. West Virginia University, Morgantown.

Bourne, C. M., D. G. Kehler, Y. F. Wiersma, D. Cote. 2011. Barriers to fish passage and barriers to fish passage assessments: the impact of assessment methods and assumptions on barrier identification and quantification of watershed connectivity. Aquatic Ecology 45: 389-403.

Bouska, W. W., and C. P. Paukert. 2009. Road crossing designs and their impact on fish assemblages of great plains stream. Transactions of the American Fisheries Society 139: 214-222.

Briggs, A. S., and T. L. Galarowicz. 2013. Fish passage through culverts in central Michigan warmwater streams. North American Journal of Fisheries Management 33: 652-664. 
Burford, D. D., T. E. McMahon, J. E. Cahoon, and M. Blank. 2009. Assessment of trout passage through culverts in a large Montana drainage during summer low flow. North American Journal of Fisheries Management 29: 739-752.

Dunham, J. B., and B. E. Rieman. 1999. Metapopulation structure of bull trout: influences of physical, biotic, and geometrical landscape characteristics. Ecological Applications 9: 642-655.

Dunham, J. B., G. L. Vinyard, and B. E. Rieman. 1997. Habitat fragmentation and extinction risk of Lahontan cutthroat trout. North American Journal of Fisheries Management 17: 11261133.

Fagan, W. F. 2002. Connectivity, fragmentation and extinction risk in dendritic metapopulations. Ecological Society of America 83: 3243-3249.

Fausch, K. D., C. E. Torgersen, C. V. Baxter, and H. W. Li. 2002. Landscape to riverscapes: bridging the gap between research and conservation of stream fishes. Bioscience 52: 483497.

Fausch, K. D., and K. R. Bestgen. 1997. Ecology of fishes indigenous to central and southwestern Great Plains. Pages 131-166 in F. L. Knopft and F. B. Samson, editors. Ecology and Conservation of Great Plains Vertebrates. New York: Springer-Verlag. Ecological Studies 125.

Gerking, S. D. 1959. The restricted movement of fish populations. Biological Reviews of the Cambridge Philosophical Society 34: 221-242.

Gibson, R. J., R. L. Haedrich, and C. M. Wernerheim. 2005. Loss of fish habitat as a consequence of inappropriately constructed stream crossings. Fisheries 30: 10-17.

Gowan, C., M. K. Young, K. d. Fausch, and S. C. Riley. 1994. Restricted movement in resident stream salmonids: a paradigm lost? Canadian Journal of Fisheries and Aquatic Sciences 51: 2626-2637.

Hansbarger, J. L., J. T. Petty, and P. M. Mazik. 2010. Brook trout movement within a highelevation watershed: consequences for watershed restoration. Proceedings from the Conference on the Ecology and Management of High-Elevation Forests in the Central and Southern Appalachian Mountains. 74-84.

Hankski, I. 1999. Habitat connectivity, habitat continuity, and metapopulations in dynamic landscapes. Oikos 87: 209-219.

Hanski, I., T. Pakkala, M. Kuussaari, and G. Lei. 1995. Metapopulation persistence of an endangered butterfly in a fragmented landscape. Oikos 72: 21-28. 
Hansbarger, J. L., J. T. Petty, and P. M. Mazik. 2010. Brook Trout Movement within a highelevation watershed: consequences for watershed restoration. Proceedings from the Conference on the Ecology and Management of High-Elevation Forests in the Central and Southern Appalachian Mountains. 74-84.

Hudy, M., T. M. Thieling, N. Gillespie, and E. P. Smith. 2008. Distribution, status, and land use characteristics of subwatersheds within the native range of brook trout in the eastern United States. North American Journal of Fisheries Management 28:1069-1085.

Hudy, M., J. A. Coombs, K. H. Nislow., and B. H. Letcher. 2010. Dispersal and within-stream population structure of brook trout revealed by pedigree reconstruction analysis. Transactions of the American Fisheries Society 139: 1276-1287.

Hutchings, J. A., A. Pickle, C. R. McGregor-Shaw, and L. Poirier. 1999. Influence of sex, body size, and reproduction on overwinter lipid depletion in brook trout. Journal of Fish Biology 55: 1020-1028.

Kanno, Y., J. C. Vokoun, and B. H. Letcher. 2011. Fine-scale population structure and riverscape genetics of brook trout (Salvelinus fontinalis) distributed continuously along headwater channel networks. Molecular ecology 20: 3711-3729.

Knaepkens, G., E. Verheyen, P. Galbusera, and M. Eens. 2004. The use of genetic tools for the evaluation of a potential migration barrier for the bullhead. Journal of Fish Biology 64: 1737-1744.

Kondratieff, M. C., and C. A. Myrick. 2006. How high can a brook trout jump? A laboratory evaluations of brook trout jumping performance. Transactions of the American Fisheries Society 135:361-370.

Larson, G. L., and S. E. Moore. 1985. Encroachment of exotic rainbow trout into stream populations of native brook trout in the southern Appalachian mountains. Transactions of the American Fisheries Society 114: 195-203.

Letcher, B.H., K. H. Nislow, J. A. Coombs, M. J. O’Donnell, and T. L. Dubreuil. 2007. Population response to habitat fragmentation in a stream-dwelling brook trout population. Plos One 2: 1-11.

Levins, R. 1969. Some demographic and genetic consequences of environmental heterogeneity for biological control. Bulletin of the Entomological Society of America 15: 237-240.

Love, M., and R. N. Taylor. 2003. Fish passage evaluation at stream crossings. California salmonid stream habitat restoration manual part IX. Available at http://www.dfg.ca.gov/nafwb/pubs/2003/FishPassage.pdf.

Marschall, E. A., and L. B. Crowder. 1996. Assessing population responses to multiple anthropogenic effects: a case study with brook trout. Ecological Applications 6(1): 152167. 
MacPherson, L. M., M. G. Sullivan, A. L. Foote, and C. E. Stevens. 2012. Effects of culverts on stream fish assemblages in the Alberta foothills. North American Journal of Fisheries Management 32: 480-490.

Martin, R. W., and J. T. Petty. 2009. Local stream temperature and drainage network topology interact to influence the distribution of smallmouth bass and brook trout in a central Appalachian watershed. Journal of Freshwater Ecology 24:497-508.

Morita, K., and A. Yokota. 2002. Population viability of stream-resident salmonids after habitat fragmentation: a case study with white-spotted charr (Salvelinus leucomaenis) by an individual based model. Ecological Modelling 155: 85-94.

Mount, D. R., C. G. Ingersoll, D. D. Gulley, J. D. Fernandez, T. W. LaPoint, and H. L. Bergman. 1988. Effect of long-term exposure to acid, aluminum, and low calcium on adult brook trout (Salvelinus fontinalis). 1. Survival, growth, fecundity, and progeny survival. Canadian Journal of Fisheries and Aquatic Sciences 45: 1623-1632.

Nagel, J.W. 1991. Is the decline of brook trout in the southern Appalachians resulting from competitive exclusion and/or extinction due to habitat fragmentation? Journal of the Tennessee Academy of Science 66:141-143.

Nakamura, T., T. Maruyama, and S. Watanabe. 2002. Residency and movement of streamdwelling Japanese charr, Salvelinus leucomaenis, in a central Japanese mountain stream. Ecology of Freshwater Fish 11: 150-157.

Neraas, L. P., and P. Spruell. 2001. Fragmentation of riverine systems: the genetic effects of dams on bull trout (Salvelinus confluentus) in the Clark Fork River system. Molecular Ecology 10: 1153-1164.

Nehlsen, W., J. E. Williams, and J. A. Lichatowich. 1991. Pacific salmon at the crossroads: stocks at risk from California, Oregon, Idaho, and Washington. Fisheries 16: 4-21.

Neville, H., J. Dunham, A. Rosenberger, J. Umek, and B. Nelson. 2009. Influences of wildfire, habitat size, and connectivity on trout in headwater streams revealed by patterns of genetic diversity. Transactions of the American Fisheries Society 138:1314-1327.

Nilsson, J. 1992. Genetic variation in resistance of Arctic char to fungal infection. Journal of Aquatic Animal Health 4: 126-128.

Nislow, K. H., and W. H. Lowe. 2006. Influences of logging history and riparian forest characteristics on macroinvertebrates and brook trout (Salvelinus fontinalis) in headwater streams (New Hampshire, U.S.A.). Freshwater Biology 51: 388-397.

Nislow, K. H., M. Hudy, B. H. Letcher, and E. P. Smith. 2011. Variation in local abundance and species richness of stream fishes in relation to dispersal barriers: implications for management and conservation. Freshwater Biology 56: 2135-2144. 
Park, D. M., Sullivan, E. Bayne, and G. Scrimgeour. 2008. Landscape-level stream fragmentation caused by hanging culverts along roads in Alberts's boreal forest. Canadian Journal of Forestry Research 38: 566-575.

Petty, J. T., and G. D. Grossman. 2004. Restricted movement by mottled sculpin (pisces: cottidae) in a southern Appalachian stream. Freshwater Biology 49: 631-645.

Petty, J. T., J. L. Hansbarger, and B. M. Huntsman. 2012. Brook trout movement in response to temperature, flow and thermal refugia within a complex Appalachian riverscape. Transactions of the American Fisheries Society 141: 1060-1073.

Petty. J. T., P. J. Lamothe, and P. M. Mazik. 2005. Spatial and seasonal dynamics of brook Trout populations inhabiting a central Appalachian watershed. Transactions of the American Fisheries Society 134:572-587.

Poplar-Jeffers, I. O., J. T. Petty, J. T. Anderson, S. J. Kite, M. P. Strager, and R. H Fortney. 2009. Culvert replacement and stream habitat restoration: implications from brook trout management in an Appalachian watershed, U.S.A. Restoration Ecology 17: 404-413.

Powers, D. A., I. Ropson, D. C. Brown, R. Van Beneden, R. Cashon, L. I. Gonzalez-Villasenor, and J. A. DiMichele. 1986. Genetic Variation in Fundulus heteroclitus: geographic distribution. American Zoologist 26: 131-144.

Pulliam, H. R. 1988. Sources, sinks, and population regulation. The American Naturalist 132: 652-661.

Raymond, H. L. 1979. Effects of dams and impoundments on migrations of juvenile chinook salmon and steelhead from the Snake River, 1966 to 1975. Transactions of the American Fisheries Society 108: 505-529.

Riley, C. 2004. Fish passage at selected culverts on the Hoonah Ranger District, Tongrass National Forest. Proceedings of the 2003 International Conference on the Ecology and Transportation. 73-82.

Robinson, G. D., W. A. Dunson, J. E. Wright, and G. E. Mamolito. 1976. Differences in low pH tolerance among strains of brook trout (Salvelinus fontinalis). Journal of Fish Biology 8: $5-17$.

Rogers, S. M., and R. A. Curry. 2004. Genetic population structure of brook trout inhabiting larger river watershed. Transactions of the American Fisheries Society 133:1138-1149.

Schlosser, I.J. 1995. Critical landscape attributes that influence fish population dynamics in headwater streams. Hydrobiologia 303: 717-81.

Schlosser, I.J. 1998. Fish recruitment, dispersal, and trophic interactions in a heterogeneous lotic environment. Oecologia 113: 260-268. 
Smithson, E.B., and C. E. Johnston. 1999. Movement patterns of stream fishes in a Ouachita Highlands stream: an examination of the restricted movement paradigm. Transactions of the American Fisheries Society 128: 847-853.

Snyder, R.J., and H. Dingle. 1989. Adaptive, genetically-based differences in life history estuary and freshwater threespine sticklebacks (Gasterosteus aculeatus L.). Canadian Journal of Zoology 67: 2448-2454.

Schwartz, M. K., G. Luikart, and R. S. Waples. 2006. Genetic monitoring as a promising tool for conservation and management. Trends in Ecology and Evolution 22: 25-33.

Sotiropoulos, J. C., K. H. Nislow, and M. R. Ross. 2006. Brook trout, Salvelinus fontinlas, microhabitat selection and diet under low summer stream flows. Fisheries Management and Ecology 13: 149-155.

Stolarski, J. T., and K. J. Hartman. 2010. Comparison of growth and condition of fluvial and resident brook trout within partially migratory populations. Fisheries Management and Ecology 17:33-39.

USACE (U.S. Army Corps of Engineers). 2013. National inventory of dams data. USACE, Washington, D.C. Available: www.usace.army.mil (November 2013)

Utz, R.M., and K. J. Hartman. 2006. Termporal and spatial variation in the energy intake of brook trout (Salvelinus fontinalis) population in an Appalachian watershed. Canadian Journal of Fisheries and Aquatic Sciences 63: 2675-2686.

Vander Pluym, J. L., D. B. Eggleston, and J. F. Levine. 2008. Impacts of road crossings on fish movement and community structure. Journal of Freshwater Ecology 23:565-574.

Warren, Jr. M. L., and M. G. Pardew. 1998. Road crossings as barriers to small-stream fish movement. Transactions of the American Fisheries Society 127: 637-644.

Webster, J. S., and K. J. Hartman. 2007. Possible seasonal population bottlenecks in brook trout (Salvelinus fontinalis) in central Appalachian headwater streams. Journal of Freshwater Ecology 22: 177-187.

Wofford, J. E. B., R. E. Gresswell, and M. A. Banks. 2005. Influence of barriers to movement on within-watershed genetic variation of coastal cutthroat trout. Ecologlical Applications 15: 628-637.

Xu, C. L., B. H. Letcher, and K. H. Nislow. 2010. Size-dependent survival of brook trout Salvelinus fontinalis in summer: effects of water temperature and stream flow. Journal of Fish Biology 76: 2342-2369. 


\title{
Chapter 2
}

\section{Effects of Culverts on Brook Trout Genetic Diversity}

\begin{abstract}
Brook trout (Salvelinus fontinalis) are a species of concern within their native range due to a historical loss of habitat, overfishing, and stocking of non-native salmonids. Road culverts have been recognized as an additional impediment to population persistence as movement between diverse habitat types has been identified as an alternative life-history strategy to maximize spawning and growth. Brook trout were genetically analyzed using a suite of 13 microsatellite loci above 7 culverts with varying levels of passability classified through a physical protocol. While most sites were not found to have losses in genetic diversity, populations above culverts with a high outlet drop were found to have significant population differentiation when compared to streams with passable culverts and streams without culverts. These results suggest that prioritization of headwater stream restoration efforts should focus on culverts with high outlet drops.
\end{abstract}

\section{Introduction}

Headwater streams possess the essential chemical, physical, and biological conditions required for sustained brook trout (Salvelinus fontinalis) survival and reproduction (Petty et al. 2005). Occurring as small channelized bodies of water, a headwater stream's functionality is inherently influenced by its spatial surroundings (Vannote et al. 1980) and can vary in chemical, physical and biological states temporally (Hildrew and Giller 1994; Petty et al. 2012). While flow connects streams into a continuous hydrologic network spanning multiple scales and environments, access to diverse habitat types in a riverscape (Fausch et al. 2002) has been 
identified as an essential life history strategy for brook trout to maximize both reproduction and growth (Petty et al. 2005; Utz and Hartman 2006; Hansbarger et al. 2010; Stolarski and Hartman 2010). However, as individual mobility increases past the natal home range and into multiple stream reaches, the likelihood of encountering movement barriers becomes more probable as aquatic habitats are very susceptible to spatial disconnect. Fragmentation of spatially linked habitats reduces the ability to access multiple habitats and hinders population persistence during periods of extinction by reducing the ability to colonize vacant patches of refugia (Nagel 1991; Dunham and Rieman 1999; Hanski 1999; Fagan 2002; Letcher et al. 2007; Bertolo et al. 2008).

Although natural fragmentation of aquatic habitats occurs spatially (e.g. waterfalls, cascades) (Wofford et al. 2005) and temporally (e.g. drought, ephemeral streams) (Fausch and Bestgen 1997), road culverts have been identified as artificial sources of movement barriers (Warren and Pardew 1998) due to steep interior slopes (Poplar-Jeffers et al. 2009), insufficient water depth (Gibson et al. 2005), high outlet drop (Riley 2004;Poplar-Jeffers et al. 2009; Burford et al. 2009; MacPherson et al. 2012), increased water velocities (Belford and Gould 1989; Gibson et al. 2009), and culvert length (Bouska and Paukert 2009; Biggs and Galarwoicz 2013). However, passability varies between individual culverts as physical and environment conditions shift frequently, especially when considering a headwater stream's spatiotemporal variability (Vander Pluym et al. 2008).

Biological methods to infer culvert passability have relied on indicators of species diversity above and below culverted stream sections (Nislow et al. 2011) as well as mark and recapture of individuals (Warren and Pardew 1998; Vander Pluym et al. 2008). However, mark and recapture has received criticism for low recapture rates of individuals (Smithson and Johnston 1999; Nakamura et al. 2002) and species diversity indices vary with temporal 
migrations (Gowan and Faush 1996), therefore challenging the validity of either method to assess culvert passability with confidence.

As an alternative to biological assessments, evaluations of the physical characteristics of individual culverts are used to assess passability (Poplar-Jeffers et al. 2009). Additionally, software programs, such as Fish Xing, use hydrologic parameters (flow velocity, depth, etc.) and physical measurements of the culvert along with species-specific swim data to simulate passability at several life stages. However, Poplar-Jeffers et al. (2009) noted exclusivity of all culverts to passability when classifying state-owned culverts in West Virginia utilizing the Fish Xing software and found through a protocol adopted by California (Love and Taylor 2003), that only $70 \%$ of culverts were classified as impassable (Poplar-Jeffers et al. 2009). Additionally, while these procedures included known swim data, using physical evaluations as a lone classification system fails to include current fish population dynamics as a verification of physical assessments.

Genetic analysis has emerged as a powerful tool to detect fine-scale structure in brook trout populations (Angers et al. 2005; Hudy et al. 2010; Kanno et al. 2011) and has been used previously to verify culvert passability for coastal cutthroat trout Oncorhynchus clarki clarki (Wofford et al. 2005) and bullhead catfish Cottus gobio (Knaepkens et al. 2004). Given the importance of movement as an alternative life history strategy for brook trout, density of culverts found in headwater streams, and multiple culvert assessment procedures, genetic analysis is needed to validate physical culvert classifications for future management procedures. 
The objectives of this study are to classify culverts based on the Phase I, Love and Taylor (2003) protocol (Figure 1) and use genetic data to evaluate whether the classifications reflect true passability for brook trout. I hypothesize that there will be significant genetic differentiation of populations above culverts classified, through the Love and Taylor (2003) protocol, as impassable. I also expect that those culverts, which have been historically impassable, will also have losses in genetic diversity, as measured by allelic richness and heterozygosity. For culverts classified as partially passable, I expect to see moderate levels of genetic differentiation, while I expect to see no change for those classified as passable.

\section{Methods}

Study Area

The study is located entirely in the Upper Shavers Fork watershed of the Monongahela National Forest, located in Pocahontas and Randolph counties of eastern West Virginia (Figure 2). Historically (prior to 1910), the Upper Shavers Fork was a naturally productive region for brook trout; however the abundance of red spruce Picea rubens attracted a logging industry to the headwaters of the watershed. Subsequently a railroad was built to the town of Spruce paralleling the edge of the Shavers Fork mainstem. During this construction, multiple culverts were installed within the headwater streams near the confluence of those streams and the mainstem, possibly cutting off dispersal for some individuals.

The mainstem of the Shavers Fork watershed is a large, productive system exhibiting a significantly more diverse fish community compared to tributaries (Bopp 2002). Brook trout residing in the Shavers Fork mainstem exhibit high daily rates of movement (50 m/day) (Petty et al. 2012), which allows for spatial linkages among populations inhabiting smaller tributaries. 
However, abiotic factors such as basin size and lack of suitable substrate prohibit brook trout from spawning in the mainstem, requiring brook trout to return to smaller, alkaline headwater streams (Petty et al. 2005).

\section{Culvert Surveying and Classification}

For all culverted stream sites, a Leica Geosystems laser and rod was used to complete a longitudinal profile of the stream starting from the tailwater control of the first resting habitat upstream of the culvert until the tailwater control of the plunge pool. In addition, a crosssectional survey was conducted at the maximum depth of the plunge pool below the culvert. After the survey, classification of each culvert followed the Phase I Love and Taylor (2003) protocol where culverts classified as "Red" were deemed impassable, "Grey" were identified as partially passable, and "Green" were purportedly passable.

\section{Fish sampling and Tissue Collection}

Second and third order tributaries off of the Shavers Fork mainstem were sampled including Rocky Run, Beaver Creek, Lamothe Hollow, Buck Run, Black Run, Dark Run, Spruce Run, and Oates Run (Figure 1). Previous mapping efforts have named two Black Runs, however for the purposes of this study, Black Run near the headwaters was renamed Dark Run. Sampling occurred in June 2011 for Beaver Creek, and during the months of June and July 2012, 2013 for all other tributaries. Due to the proximity of some culverts to the Shavers Fork mainstem, fish sampling below the culvert was limited to a minority of culverted sites (Spruce, Black Run, Buck Run). The sampling design of control streams (i.e. no culvert or other barriers), Rocky Run and Dark Run, mimicked streams inhabited by a culvert by establishing a 300 meter stream section 
between upper and lower sampled stream sections to account for any spatial differences in culverted sites.

Brook trout from multiple cohorts were collected via backpack electrofishing (Model LR24, Smith Root, Vancouver, Washington) in a 150 meter, single upstream pass and were anesthetized using clove oil. Fin clips from the adipose and caudal fin were taken and preserved in $95 \%$ ethanol until extraction.

\section{Genetic Protocols}

Genomic DNA was extracted by using the Wizard ${ }^{\circledR}$ SV-96 DNA purification system (Promega, Madison, WI) according to manufacturer's protocol. Extracted DNA was quantified using a spectrophotometer (NanoDrop, Wilmington, DE) and standardized to a concentration of $10 \mathrm{ng} / \mu \mathrm{L}$. A suite of thirteen microsatellite loci described in King et al. (2012) were amplified using either a MJ Research PCT-200 or BioRad C1000 thermocycler using $10 \mu \mathrm{L}$ reactions with $2 \mu \mathrm{L}$ of DNA. The amplification protocol for loci Sfo-B52, Sfo-C79, Sfo-D100, Sfo-C24, SfoC28, Sfo-C115, Sfo-C113 started with an initial heating of $94^{\circ} \mathrm{C}$ and then 35 cycles of $94^{\circ} \mathrm{C}(30$ $\mathrm{sec}), 56^{\circ} \mathrm{C}(30 \mathrm{sec}), 72^{\circ} \mathrm{C}(45 \mathrm{sec})$, with a final hold of $72^{\circ} \mathrm{C}$ for 10 minutes (King et al. 2012). Loci Sfo-C86, Sfo-D91, Sfo-C38, Sfo-D100, Sfo-C88, Sfo-C129 were initially heated at $94^{\circ} \mathrm{C}$ and continued with 15 cycles of $94^{\circ} \mathrm{C}(45 \mathrm{sec}), 60^{\circ} \mathrm{C}(45 \mathrm{sec})$ with a decrease of $0.5^{\circ} \mathrm{C}$ per cycle, and $72^{\circ} \mathrm{C}(30 \mathrm{sec})$. The protocol continued for an additional 15 cycles of $94^{\circ} \mathrm{C}(45 \mathrm{sec})$, $52^{\circ} \mathrm{C}(45 \mathrm{sec})$, and $72^{\circ}(30 \mathrm{sec})$. Resultant fragments were genotyped using GenomeLab ${ }^{\mathrm{TM}}$ GeXP genetic analysis system (Beckman Coulter, Brea, California), scored using associated software, and checked by a single individual. 


\section{Genetic Analysis}

Each of the 14 sampling sites was treated as an individual population. Detection of possible genotyping errors or null alleles was through Micro-Checker version 2.2.3 (Van Oosterhout et al. 2004). Deviations from Hardy-Weinberg Equilibrium (HWE) were tested in Genepop (Raymond and Rousset, 1995) using 10,000 iterations.

\section{Genetic Analysis- Genetic diversity and population differentiation}

Allele frequencies, allelic richness, expected heterozygosity, and genetic differentiation ( $\mathrm{F}_{\mathrm{ST}}$; Wright 1951) were calculated using the software FSTAT version 2.9.3 (Goudet 2001). Significant differences in allelic richness between culverted sites and control sites (no culverts) were compared using a paired two-sample T-test. A Shapiro-Wilks test (R Development Team, 2008) was used to ensure the assumption of normality was fulfilled. Observed heterozygosity $\left(\mathrm{H}_{\mathrm{o}}\right)$ was calculated in Arlequin ver 3.5.1.3 (Excoffier and Lischer, 2010) and a paired-two sample T-test was used to examine any significant differences in observed heterozygosity $\left(\mathrm{H}_{\mathrm{O}}\right)$ between culverted sites and control sites (no culverts). A Shapiro-Wilks test (R Development Team, 2008) was used to ensure the assumption of normality between paired differences of observed heterozygosity $\left(\mathrm{H}_{\mathrm{O}}\right)$ was fullfilled.

A sequential Bonferonni correction (Rice 1989) was used to correct the significance of each $\mathrm{F}_{\mathrm{ST}}$ value for multiple comparisons. In addition, a Mantel test was executed in $\mathrm{R}$, ( $\mathrm{R}$ Development Team, 2008) using the package eco dist (Goslee and Urban 2007) to determine if genetic differentiation was related to geographic distance between sampling sites. To test for population differentiation between sites, pairwise F $_{\text {ST }}$ values for populations above red and grey culverts were compared to both control sites. Additionally, pairwise FST for populations above 
green culverts and control sites were compared to sites within the same stream. A regression analysis was also performed in R, (R Development Team, 2008) to examine any significant relationship between the allelic richness and basin size.

To determine the most likely number of populations $K$, the Bayesian software STRUCTURE (Pritchard et al. 2000) was implemented using an admixture model and 5 iterations of possible values for $K=1-16$ (100,000 burn-ins and 100,000 Monte-Carlo Markov Chain repetitions). The results of STRUCTURE were imported into the software STRUCTURE HARVESTER (Earl and vonHoldt, 2012) to visually determine the most likely value of $K$ by examining the log likelihood and $\Delta K$ (Evanno et al. 2005).

An additional run of STRUCTURE was conducted using an admixture model and the sampling locations as priors. As before, five iterations of possible values for $K=1-16(100,000$ burn-ins and 100,000 Monte-Carlo Markov Chain repetitions) were set and the results were imported into STRUCTURE HARVESTER (Earl and vonHoldt, 2012) to visually determine the most likely value of K (Evanno et al. 2005). A phylogenetic diagram of the population structure was created through 1,000 bootstrap replicates in PHYLIP version 3.695 (Felsenstein 2005) using Cavalli-Sforza genetic distances (Cavalli-Sforza and Edwards 1967) and viewed by the software Tree View (Page 1996).

To determine possible genetic barriers, the software Barrier, version 2.2 (Manni et al. 2004) was implemented to test where possible genetic barriers may exist by using the geographic coordinates of the sampling locations as well genetic differences calculated through 1000 replicates of Cavalli-Sforza genetic distances (Cavalli-Sforza and Edwards 1967) calculated by PHYLIP version 3.695 (Felsenstein 2005). The geographic foundation of Barrier is established 
on two geometric principles, Delauny triangulation and Voronoï tessellation. Voronoï tessellation creates polygons around the centroid (sampling point) to divide up the geographic space such that each vertex in the polygon is equidistant from the centroid (locations of sampled populations) (Manni and Guérard 2004). Delauny triangulation connects those sampling points that are within the circumference of a circle originating from each sampling point to the next closest sampling point, therefore limiting the number of expected "connected" populations to neighboring sampling points (populations). Finally, Barrier applies Monmonier's (1973) maximum difference algorithm to the pairwise genetic distances and identifies a barrier between to those populations that are connected by Delauny triangulation, but are genetically differentiated.

\section{Results}

\section{Culvert Assessment}

A total of seven culverts were located, surveyed, and classified (Figure 2). Three of these culverts (Beaver Creek, Lamothe Hollow, and Oates Run) were determined to be impassable "red". The culverts at Beaver Creek and Lamothe Hollow were classified as impassable due to high outlet drops whereas the culvert at Oates Run was impassable because of steep interior slopes $\left(>3^{\circ}\right)$ as well as a long culvert length $(40 \mathrm{~m})$ without the presence of baffles or weirs. Two culverts, located at Black Run (near the confluence of the mainstem) and Spruce Run were found to be partially impassable "grey" due to small outlet drops. Although these outlet drops were significantly shorter than Beaver Creek and Lamothe Hollow, they still could preclude movement of juvenile brook trout. In addition, two culverts located at Black Run and Buck Run were deemed as completely passable "green" to all brook trout life stages. Two additional 
streams were located (Rocky Run, Dark Run) that did not have any culverts. Although control streams were not classified due to the absence of a culvert, no apparent natural barrier was observed during sampling.

\section{Genetic Diversity}

A total of 302 brook trout tissue samples were successfully genotyped from 14 sampling sites (Figure 1). No genotyping errors or null alleles were detected. Eight sampled populations (57\%) were significantly out of HWE (Table 1) due to a heterozygote deficiency (Table 2). Additionally, 8 loci significantly deviated significantly from HWE.

Expected heterozygosity $\left(\mathrm{H}_{\mathrm{e}}\right)$ ranged between $0.49-0.57$ and allelic richness from 3.173.80 (Table 1). The sampling site below the Spruce run culvert had the highest allelic richness (3.80) where as the site at Lamothe Hollow (deemed impassable) had the lowest allelic richness (3.17). Paired differences of allelic richness were normal between sampling sites and loci. Significant differences $(\mathrm{p}<0.05)$ were found between the Spruce Upper site (above partially impassable culvert) and Upper Rocky, a control site ( $\mathrm{p}=0.046)$, however it was not significantly different between Dark Upper $(\mathrm{p}=0.07)$. Although Lamothe Hollow had the lowest allelic richness (3.17), it was not statistically significant when compared to Upper Rocky $(\mathrm{p}=0.065)$ or Dark Upper $(\mathrm{p}=0.10)$

\section{Genetic Differentiation}

Significant pairwise FST $_{\text {ST }}$ differences (range $0.00-0.108$ ) were found between the majority of sampling sites (Table 3), especially when comparing the two control sites (Spruce Upper, Upper Rocky) to those sites containing an impassable barrier (Lamothe Hollow, Beaver Upper, Beaver Lower) (Table 4) where the average pairwise $\mathrm{F}_{\mathrm{ST}}$ between those sites was 0.061 
(Lamothe Hollow), 0.106 (Beaver Upper), and 0.055 (Beaver Lower). Additionally, the Mantel test (Figure 3) showed no relationship between genetic and geographic distance (Mantel $r=0.23$, $\mathrm{p}=0.98)$. There was also no relationship between allelic richness and basin $\operatorname{size}\left(\mathrm{R}^{2}=0.07, \mathrm{p}=\right.$ 0.35) (Figure 4).

Using no prior population information in STRUCTURE, the indication from the log likelihood plot (Figure 5) and the $\Delta K$ plot (Figure 6) was $K=4$ (Figure 7) with strong differentiation of the Beaver Creek sites as well as Lamothe Hollow, both above an impassable culvert. However, samples from Black Middle and Black Upper, a stream with a passable culvert (green), also showed strong differentiation. Utilizing the known sampling locations as priors, the plot of highest likelihood of K, $\mathrm{L} K$ (Figure 8) and $\Delta K$ (Figure 9) indicated the most likely number of populations of $K=5$ (Figure 10). Visually, the STRUCTURE plot (Figure 10) groups the Buck Run locations into a separate population as well as the two Beaver Creek Sites. A third grouping of Lamothe Hollow is also very distinguishable from other sites.

The phylogenetic tree (Figure 11) indicates fine scale genetic population structure of brook trout inhabiting the Upper Shavers Fork. While the two sites at Beaver Creek grouped separately from all other streams (100\%), the sites at Dark Run (control stream) also grouped independently from all other streams (66\%). Additionally, both sites at Spruce Run, stream with a grey culvert, and Buck Run, stream with green culvert, also differentiated from other streams. The Lower Rocky site, a control stream, grouped (78\%) with Lamothe Hollow, a site above an impassable culvert. 
Three significant barriers to movement (> 50\%) were detected (Figure 12) using the program Barrier (Manni et al. 2002); Beaver Creek (99\%) and Lamothe Hollow sites (90-93\%). These three sites were sampled above two culverts deemed impassable.

\section{Discussion}

A group of seven road culverts, inhabited by a historically robust brook trout population, were physically evaluated in the Upper Shavers Fork watershed and found to have varying levels of passability according to the Phase I Love and Taylor (2003) classification protocol. Two culverts, classified as completely impassable (red), exhibited symptoms of potential total impassability due to high outlet drop (Beaver Creek, Lamothe Hollow) as well as steep interior slope without the presence of baffles or weirs (Oates Run). From the genetic analysis, only two of these culverts (Beaver Creek, Lamothe Hollow) should be considered impassable due to the high levels of genetic differentiation from other sites based on the FST, Barrier, and STRUCTURE results. Although the culvert at Oates Run was classified as impassable, it showed high levels of genetic diversity and did not exhibit population differentiation, indicating the possibility of ascending the culvert at Oates Run which had a slope slightly greater than $3 \%$. Larson and Moore (1985) noted that brook trout could ascend slopes between 8-18\% in the southern Appalachian Mountains, thus supporting the possibility the culvert at Oates Run is not a barrier to upstream brook trout movement.

Additionally, although the $\mathrm{F}_{\mathrm{ST}}$ and STRUCTURE results showed signs of fine-scale population structuring, combining results from multiple analyses revealed that populations above both grey and green culverts allow for brook trout migration. Therefore, before future application 
of the Love and Taylor (2003) protocol to classify culverts in headwater streams, slight modifications need to be made to emphasize the swimming abilities of brook trout.

\section{Genetic Diversity}

Allelic richness $\left(\mathrm{R}_{\mathrm{S}}\right)$ was hypothesized to be lowest in culverts classified as red (completely impassable), especially those with high outlet drops $(>0.61 \mathrm{~m})$ as they exceed the jumping ability of brook trout (Kondratieff and Myrick 2006). However, the Spruce Upper site, classified as partially impassable (Grey), was the only stream section with significantly lower allelic richness when compared to a control stream (Upper Rocky). These results are contrasting to other salmonid studies (Nielsen et al., 1997, Morita and Yamamota 2002) which found that fish above movement barriers in place longer than 30 years lost genetic diversity. The culverts at Lamothe Hollow and Beaver Creek were in place greater than 100 years while the culvert at Oates Run has only been in place for approximately 25 years (P. Kinder, West Virginia University, personal communication). The results of this study do concur with those found of Knaepkens et al. (2004) who noted comparable levels of genetic diversity of bullhead Cottus gobio above and below culverted stream sections. These results also concur with Rogers and Curry (2004) who found that variables other than distance were significant in influencing the divergence of brook trout populations within the same watershed.

\section{Population Analysis}

While measures of genetic diversity between varying levels of culvert passability failed to confirm or refute physical culvert classifications, analysis of genetic population structures revealed relatively distinct genetic patterns of population differentiation. The STRUCTURE results showed individuals above two different culverted (Beaver Creek, Lamothe Hollow) 
sections displayed significant population divergence from other sites (Table 2). The ability to detect fine scale genetic differences in brook trout due to barriers was also observed by Kanno et al. (2011) who identified population structures caused by seasonal migration barriers.

Additionally, the results of Barrier (Manni et al. 2004) (Figure 7) statistically confirmed the Lamothe Hollow and Beaver Creek sites as barriers to movement. While Barrier has been used to detect genetic barriers in open aquatic landscapes (e.g. Bergek and Björklund 2009) and partially dendritic systems (Strange and Stipien 2007), the use of this program in a highly dendritc riverscape, like the Upper Shavers Fork, proved successful in identifying barriers to gene flow at two sites, Beaver Creek and Lamothe Hollow. Both of these sites were deemed impassasble by the Love and Taylor (2003) protocol and were found to be sources of population differentiation in the STRUCTURE and FST analysis.

Riverscapes, like that of the Upper Shavers Fork, have been discussed as complex systems that are spatiotemporally influenced by varying environmental, biological, and chemical conditions (Fausch et al. 2002, Petty et al. 2012). Corresponding to the spatial complexities of riverscapes, culverts represent an additional dynamic factor that can influence the mosaic of stream connectivity, especially when considering the varying physical features that influence organism passability. While movement has been identified as an influential element to the lifehistory strategy of brook trout (Petty et al. 2005, Hansbarger et al. 2010, Utz and Hartman 2005), measuring the population response to variances must be measured on an appropriate scale that considers the spatial complexity of the system (Anderson et al. 2010). Since dispersal movements beyond their natal range have been identified as an important life history strategy for brook trout, it is apparent that these population patterns reflect limited interaction between culverted sites. 


\section{Literature Cited}

Anderson, C. D., B. K. Epperson, M-J. Fortin, R. Holderegger, P. M. A. James, K. T. Scribner, S. Spear. 2010. Considering spatial and temporal scale in landscape-genetic studies of gene flow. Molecular Ecology 19: 3565-3575.

Angers, B., L. Bernatchez, A. Angers, and L. Desgroseillers. 1995. Specific microsatellite loci for brook charr reveal strong population subdivision on a microgeographic scale. Journal of Fish Biology 47: 177-185.

Bergek, S., and M. Björklund. 2009. Genetic and morphological divergence reveals local subdivision of perch (Perca fluviatilis L.). Biological Journal of the Linnean Society 96:746-758.

Bertolo, A., P. Morgan, and M. Plante. 2008. Linking the occurrence of brook trout with isolation and extinction in small Boreal Shield lakes. Freshwater Biology 53: 304-321.

Bopp, J. 2002. The combined effects of water chemistry, canopy cover, and basin area on benthic macroinvertebrates along a central Appalachian stream continuum. Master's thesis. West Virginia University, Morgantown.

Bouska, W. W., and C. P. Paukert. 2009. Road crossing designs and their impact on fish assemblages of great plains stream. Transactions of the American Fisheries Society 139: 214-222.

Biggs, A. S., and T. L. Galarowicz. 2013. Fish passage through culverts in central Michigan warmwater streams. North American Journal of Fisheries Management 33: 652-664.

Cavalli-Sforza, L. L., and A. W. F. Edwards. 1967. Phylogenetic analysis: models and estimation procedures. Evolution 21: 550-570.

Dunham, J. B., G. L. Vinyard, and B. E. Rieman. 1997. Habitat fragmentation and extinction risk of Lahontan cutthroat trout. North American Journal of Fisheries Management 17: 11261133.

Earl, D.A., and B. M. vonHoldt. 2012. STRUCTURE HARVESTER: a website and program for visualizing STRUCTURE and implementing the Evanno method. Conservation Genetics Resources 4: 359:361.

ESRI 2011. ArcGIS Desktop: Release 10.1. Redlands, CA: Environmental Systems Research Institute.

Evanno, G., S. Regnaut, and J. Goudet. 2005. Detecting the number of clusters of individuals using the software STRUCTURE: a simulation study. Molecular Ecology 14: 2611-2620. 
Excoffier, L., and H. E. L. Lischer. 2010. Arlequin suite ver 3.5: a new series of programs to perform population genetic analysis under Linux and Windows. Molecular Ecology Resources 10:564-567.

Fausch, K. D., C. E. Torgersen, C. V. Baxter, and H. W. Li. 2002. Landscape to riverscapes: bridging the gap between research and conservation of stream fishes. Bioscience 52: 483497.

Fausch, K. D., and K. R. Bestgen. 1997. Ecology of fishes indigenous to central and southwestern Great Plains. Pages 131-166 in F. L. Knopft and F. B. Samson, editors. Ecology and Conservation of Great Plains Vertebrates. New York: Springer-Verlag. Ecological Studies 125.

Felsenstein, J. 2005. PHYLIP (Phylogeny Inference Package) version 3.6. Distributed by the author. Department of Genome Sciences, University of Washington, Seattle.

Fitch, G. M. 1995. Nonanadromous fish passage in high culverts. Final Report. VTRC 96-R6. Virginia Transportation Research Council, Charlottesville, Virginia.

Goslee, S.C., and D. L. Urban. 2007. The ecodist package for dissimilarity-based analysis of ecological data. Journal of Statistical Software 22: 1-19.

Goudet, J. 2001. FSTAT, a program to estimate and test gene diversities and fixation indices (version 2.9.3). Available http://www2.unil.ch/popgen/softwares/fstat.html. (January 2014).

Hankski, I. 1999. Habitat connectivity, habitat continuity, and metapopulations in dynamic landscapes. Oikos 87: 209-219.

Hansbarger, J. L., J. T. Petty, and P. M. Mazik. 2010. Brook Trout Movement within a highelevation watershed: consequences for watershed restoration. Proceedings from the Conference on the Ecology and Management of High-Elevation Forests in the Central and Southern Appalachian Mountains. 74-84.

Hildrew, A. G., and P. S. Giller. 1994. Patchiness and species interactions and disturbances in the stream benthos: aquatic ecology, scale pattern, process. Pages 21-62 in P.S. Giller, A. G. Hildrew, and D. G. Raffaelli, editors. $34^{\text {th }}$ symposium of the British ecological society. Blackwell Scientific Publications, London.

Kanno, Y., J. C. Vokoun, and B. H. Letcher. 2011. Fine-scale population structure and riverscape genetics of brook trout (Salvelinus fontinalis) distributed continuously along headwater channel networks. Molecular ecology 20: 3711-3729.

Kondratieff, M. C and C. A. Myrick. 2006. How high can a brook trout jump? A laboratory evaluation of brook trout jumping performance. Transactions of the American Fisheries Society 361-370. 
King, T.L., B. A. Lubinski, M. K. Burnham-Curtis, W. Stott, and R. P. Morgan II. 2012. Tools for the management and conservation of brook trout (Salvelinus fontinalis): tri- and tetranucleotide microsatellite markers for the assessment of genetic diversity, phylogeography, and historical demographics.

Knaepkens, G., E. Verheyen, P. Galbusera, and M. Eens. 2004. The use of genetic tools for the evaluation of a potential migration barrier for the bullhead. Journal of Fish Biology 64: 1737-1744.

Larson, G. L., and S. E. Moore. 1985. Encroachment of exotic rainbow trout into stream populations of native brook trout in the southern Appalachian mountains. Transactions of the American Fisheries Society 114: 195-203.

Letcher, B.H., K. H. Nislow, J. A. Coombs, M. J. O’Donnell, and T. L. Dubreuil. 2007. Population response to habitat fragmentation in a stream-dwelling brook trout population. Plos One 2: 1-11.

Levins, R. 1969. Some demographic and genetic consequences of environmental heterogeneity for biological control. Bulletin of the Entomological Society of America 15: 237-240.

Love, M., and R. N. Taylor. 2003. Fish passage evaluation at stream crossings. California salmonid stream habitat restoration manual part IX. Available at http://www.dfg.ca.gov/nafwb/pubs/2003/FishPassage.pdf.

Manni, F., E. Guérard, and E. Heyer. 2004. Geographic patterns of (genetic, morphologic, linguistic) variation: how barriers can be detected by "Monmonier's algorithm". Human Biology 76: 173-190.

Manni, F., and E. Guérard. 2004. Barrier vs. 2.2. Manual of the user. Population genetic teach, Museum of Mankind, Paris, France.

Monmonier, M. 1973. Maximium-difference barriers: an alternative numeric regionalization method. Geographic Analysis 3: 245-261.

Nagel, J.W. 1991. Is the decline of brook trout in the southern Appalachians resulting from competitive exclusion and/or extinction due to habitat fragmentation? Journal of the Tennessee Academy of Science 66:141-143.

Page, R. D. M. 1996. Tree View: an application to display phylogenetic trees on personal computers. Computer Applied Biosciences 12:357-358.

Petty. J. T., P. J. Lamothe, and P. M. Mazik. 2005. Spatial and seasonal dynamics of brook Trout populations inhabiting a central Appalachian watershed. Transactions of the American Fisheries Society 134:572-587.

Petty, J. T., J. L. Hansbarger, and B. M. Huntsman. 2012. Brook trout movement in response to temperature, flow and thermal refugia within a complex Appalachian riverscape. Transactions of the American Fisheries Society 141: 1060-1073. 
Poplar-Jeffers, I. O., J. T. Petty, J. T. Anderson, S. J. Kite, M. P. Strager, and R. H Fortney. 2009. Culvert replacement and stream habitat restoration: implications from brook trout management in an Appalachian watershed, U.S.A. Restoration Ecology 17: 404-413.

Pritchard, J. K., M. Stephends, and P. Donnelly. 2000. Inference of population structure using multilocus genotype data. Genetics 155: 945-959.

R Development Core Team (2008). R: A language and environment for statistical computing. R Foundation for Statistical Computing, Vienna, Austria. ISBN 3-900051-07-0, URL http://www.R-project.org.

Raymond, M., and F. Rousset. 1995. GENEPOP (version 1.2): population genetics software for exact tests and ecumenicism. Journal of Heredity 86:248-249

Rice, W. R. 1989. Analyzing tables of statistical tests. Evolution 43: 223-225.

Rogers, S. M., and R. A. Curry. 2004. Genetic population structure of brook trout inhabiting a larger river watershed. Transactions of the American Fisheries Society 133:1138-1149.

Stolarski, J. T., and K. J. Hartman. 2010. Comparison of growth and condition of fluvial and resident brook trout within partially migratory populations. Fisheries Management and Ecology 17:33-39.

Strange, R. M., and C. A. Stepien. 2007. Genetic divergence and connectivity among river and reef spawning groups of walleye (Sander vitreus vitreus) in Lake Erie. Canadian Journal of Fisheries and Aquatic Sciences 64:437-448.

Utz, R.M., and K. J. Hartman. 2006. Termporal and spatial variation in the energy intake of brook trout (Salvelinus fontinalis) population in an Appalachian watershed. Canadian Journal of Fisheries and Aquatic Sciences 63: 2675-2686.

Vander Pluym, J. L., D. B. Eggleston, and J. F. Levine. 2008. Impacts of road crossings on fish movement and community structure. Journal of Freshwater Ecology 23:565-574.

Van Oosterhout, C., W. F. Hutchinson. D. P. M. Willis, and P. Shipley. 2004. MICROCHECKER: software for identifying and correcting genotyping errors in microsatellite data. Molecular Ecology Notes 4:535-538.

Vannote, R. L., G. W. Minshall, K. W. Cummins, J. R. Sedell, and C. E. Cushing. 1980. The river continuum concept. Canadian Journal of Fisheries and Aquatic Sciences 37: 130137.

Warren, Jr. M. L., and M. G. Pardew. 1998. Road crossings as barriers to small-stream fish movement. Transactions of the American Fisheries Society 127: 637-644. 
Wilson. G. A., and B. Rannala. 2003. Bayesian inference of recent migration rates using multilocus genotypes. Genetics 163: 1177-1191.

Wofford, J. E. B., R. E. Gresswell, and M. A. Banks. 2005. Influence of barriers to movement on within-watershed genetic variation of coastal cutthroat trout. Ecologlical Applications 15: 628-637.

Wright, S. 1951. The genetical structure of populations. Annals of Eugenics 15: 323-345. 
Table 1. Sampled sites along with culvert classification, size of basin area $\left(\mathrm{km}^{2}\right)$, number of samples, observed heterozygosity $\left(\mathrm{H}_{\mathrm{o}}\right)$, expected heterozygosity $\left(\mathrm{H}_{\mathrm{e}}\right)$, and average allelic richness $\left(\mathrm{R}_{\mathrm{S}}\right)$.

\begin{tabular}{|c|c|c|c|c|c|c|}
\hline Site & $\begin{array}{c}\text { Culvert } \\
\text { Classification }\end{array}$ & $\begin{array}{c}\text { Basin Size } \\
\left(\mathrm{km}^{2}\right)\end{array}$ & $\begin{array}{c}\text { Number } \\
\text { of samples }(\mathrm{N})\end{array}$ & $\begin{array}{c}\text { Observed } \\
\text { Heterozyosity }\left(\mathrm{H}_{\mathrm{o}}\right)\end{array}$ & $\begin{array}{c}\text { Expected } \\
\text { Heterozygosity }\left(\mathrm{H}_{\mathrm{e}}\right)\end{array}$ & $\begin{array}{c}\text { Average } \\
\text { Allelic Richness }\left(\mathrm{R}_{\mathrm{S}}\right)\end{array}$ \\
\hline Buck Upper & Green & 2.65 & 25 & $0.51 *$ & 0.53 & 3.50 \\
\hline Buck Middle & None & 2.65 & 30 & $0.51 *$ & 0.53 & 3.53 \\
\hline Oates Run & Red & 1.32 & 30 & $0.45 *$ & 0.53 & 3.62 \\
\hline Black Upper & Green & 4.27 & 28 & $0.48 *$ & 0.57 & 3.61 \\
\hline Black Middle & Grey & 4.27 & 24 & $0.49 *$ & 0.52 & 3.66 \\
\hline Upper Rocky Run & Control & 6.58 & 21 & $0.46^{*}$ & 0.52 & 3.71 \\
\hline Lower Rocky Run & Control & 6.58 & 11 & 0.48 & 0.50 & 3.46 \\
\hline Lamothe Hollow & Red & 1.31 & 25 & $0.44 *$ & 0.49 & 3.17 \\
\hline Spruce Lower & None & 2.38 & 24 & $0.50 *$ & 0.52 & 3.60 \\
\hline Spruce Upper & Grey & 2.38 & 21 & 0.48 & 0.49 & 3.26 \\
\hline Dark Run Lower & Control & 5.43 & 17 & 0.53 & 0.53 & 3.80 \\
\hline Dark Run Upper & Control & 5.43 & 21 & 0.47 & 0.52 & 3.55 \\
\hline $\begin{array}{l}\text { Beaver Creek } \\
\text { Upper }\end{array}$ & Red & 4.37 & 7 & 0.46 & 0.56 & 3.54 \\
\hline $\begin{array}{l}\text { Beaver Creek } \\
\text { Lower }\end{array}$ & Red & 4.37 & 17 & 0.52 & 0.54 & 3.56 \\
\hline Average & & 3.85 & 22 & 0.48 & 0.52 & 3.54 \\
\hline
\end{tabular}

*Indicates significant divergence ( $\mathrm{p}$ < 0.05) from Hardy-Weinberg Equilibrium (HWE) calculated through Genepop version 4.2 (Raymond and Rousset, 1995). 
Table 2. Table of statistics calculated by FSTAT version 2.9.2 (Goudet 2001) for each individual locus including observed heterozygosity $\left(\mathrm{H}_{\mathrm{o}}\right)$, expected heterozygosity $\left(\mathrm{H}_{\mathrm{e}}\right)$, number of alleles $(\mathrm{A})$, and $\mathrm{F}_{\mathrm{IS}}$.

\begin{tabular}{lcccc}
\hline Locus & $\begin{array}{c}\text { Observed } \\
\text { Heterozyosity }\left(\mathrm{H}_{\mathrm{o}}\right)\end{array}$ & $\begin{array}{c}\text { Expected } \\
\text { Heterozygosity }\left(\mathrm{H}_{\mathrm{e}}\right)\end{array}$ & $\begin{array}{c}\text { Number of } \\
\text { Alleles (A) }\end{array}$ & FIS \\
\hline Sfo-B52 & 0.585 & 0.853 & 11 & 0.092 \\
Sfo-D75 & 0.790 & 0.805 & 12 & 0.052 \\
Sfo-C38 & 0.529 & 0.574 & 5 & 0.115 \\
Sfo-D91 & 0.102 & 0.059 & 12 & 0.294 \\
Sfo-C79 & 0.102 & 0.298 & 2 & 0.195 \\
Sfo-C86 & 0.617 & 0.710 & 7 & 0.000 \\
Sfo-D100 & 0.746 & 0.604 & 13 & 0.016 \\
Sfo-C113 & 0.672 & 0.469 & 10 & 0.000 \\
Sfo-C115 & 0.674 & 0.831 & 15 & 0.113 \\
Sfo-C88 & 0.700 & 0.697 & 7 & 0.000 \\
Sfo-C129 & 0.024 & 0.221 & 7 & 0.762 \\
Sfo-C28 & 0.641 & 0.577 & 9 & 0.047 \\
Sfo-C24 & 0.229 & 0.381 & 5 & 0.048 \\
& & & & \\
\hline
\end{tabular}


Table 3. Population differentiation calculated by FSTAT 2.9.3 (Goudet 2001) from populations of brook trout in the upper Shavers Fork, West Virginia, USA.

\begin{tabular}{|c|c|c|c|c|c|c|c|c|c|c|c|c|c|c|}
\hline Site & $\begin{array}{l}\text { Buck } \\
\text { Upper }\end{array}$ & $\begin{array}{l}\text { Buck } \\
\text { Middle }\end{array}$ & $\begin{array}{l}\text { Oates } \\
\text { Run }\end{array}$ & $\begin{array}{l}\text { Black } \\
\text { Upper }\end{array}$ & $\begin{array}{l}\text { Black } \\
\text { Middle }\end{array}$ & $\begin{array}{l}\text { Upper } \\
\text { Rocky }\end{array}$ & $\begin{array}{l}\text { Lower } \\
\text { Rocky }\end{array}$ & $\begin{array}{l}\text { Lamothe } \\
\text { Hollow }\end{array}$ & $\begin{array}{l}\text { Spruce } \\
\text { Lower }\end{array}$ & $\begin{array}{l}\text { Spruce } \\
\text { Upper }\end{array}$ & $\begin{array}{l}\text { Dark } \\
\text { Lower }\end{array}$ & $\begin{array}{l}\text { Dark } \\
\text { Upper }\end{array}$ & $\begin{array}{l}\text { Beaver } \\
\text { Upper }\end{array}$ & $\begin{array}{l}\text { Beaver } \\
\text { Lower }\end{array}$ \\
\hline $\begin{array}{l}\text { Buck } \\
\text { Upper }\end{array}$ & & 0.001 & 0.016 & 0.043 & 0.008 & 0.022 & 0.011 & 0.041 & 0.027 & 0.024 & 0.014 & 0.016 & 0.093 & 0.062 \\
\hline $\begin{array}{l}\text { Buck } \\
\text { Middle }\end{array}$ & 0.002 & & 0.030 & 0.059 & 0.018 & 0.023 & 0.029 & 0.041 & 0.031 & 0.030 & 0.026 & 0.037 & 0.093 & 0.067 \\
\hline Oates Run & 0.001 & 0.001 & & 0.057 & 0.027 & 0.023 & 0.014 & 0.054 & 0.019 & 0.017 & 0.005 & 0.011 & 0.096 & 0.067 \\
\hline $\begin{array}{l}\text { Black } \\
\text { Upper }\end{array}$ & 0.001 & 0.001 & 0.001 & & 0.023 & 0.051 & 0.022 & 0.047 & 0.036 & 0.042 & 0.039 & 0.035 & 0.077 & 0.045 \\
\hline $\begin{array}{l}\text { Black } \\
\text { Middle }\end{array}$ & 0.004 & 0.001 & 0.001 & 0.003 & & 0.007 & 0.0000 & 0.036 & 0.016 & 0.010 & 0.013 & 0.022 & 0.076 & 0.029 \\
\hline $\begin{array}{l}\text { Upper } \\
\text { Rocky }\end{array}$ & 0.001 & 0.001 & 0.001 & 0.001 & 0.064 & & 0.000 & 0.054 & 0.007 & 0.014 & 0.013 & 0.025 & 0.104 & 0.061 \\
\hline $\begin{array}{l}\text { Lower } \\
\text { Rocky }\end{array}$ & 0.048 & 0.002 & 0.009 & 0.003 & 0.389 & 0.508 & & 0.022 & 0.000 & 0.004 & 0.017 & 0.022 & 0.102 & 0.056 \\
\hline $\begin{array}{l}\text { Lamothe } \\
\text { Hollow }\end{array}$ & 0.001 & 0.001 & 0.001 & 0.001 & 0.001 & 0.001 & 0.002 & & 0.036 & 0.048 & 0.048 & 0.064 & 0.121 & 0.084 \\
\hline $\begin{array}{l}\text { Spruce } \\
\text { Lower }\end{array}$ & 0.001 & 0.001 & 0.001 & 0.001 & 0.002 & 0.011 & 0.296 & 0.001 & & 0.000 & 0.003 & 0.018 & 0.098 & 0.068 \\
\hline $\begin{array}{l}\text { Spruce } \\
\text { Upper }\end{array}$ & 0.001 & 0.001 & 0.001 & 0.003 & 0.077 & 0.018 & 0.119 & 0.001 & 0.754 & & 0.008 & 0.022 & 0.108 & 0.064 \\
\hline $\begin{array}{l}\text { Dark } \\
\text { Lower }\end{array}$ & 0.003 & 0.001 & 0.035 & 0.001 & 0.029 & 0.004 & 0.015 & 0.001 & 0.125 & 0.046 & & 0.000 & 0.089 & 0.059 \\
\hline $\begin{array}{l}\text { Dark } \\
\text { Upper }\end{array}$ & 0.002 & 0.001 & 0.004 & 0.001 & 0.009 & 0.001 & 0.003 & 0.001 & 0.008 & 0.012 & 0.635 & & 0.091 & 0.061 \\
\hline $\begin{array}{l}\text { Beaver } \\
\text { Upper }\end{array}$ & 0.001 & 0.001 & 0.001 & 0.001 & 0.001 & 0.001 & 0.001 & 0.001 & 0.001 & 0.002 & 0.001 & 0.001 & & 0.017 \\
\hline $\begin{array}{l}\text { Beaver } \\
\text { Lower }\end{array}$ & 0.001 & 0.001 & 0.001 & 0.001 & 0.001 & 0.001 & 0.001 & 0.001 & 0.001 & 0.001 & 0.001 & 0.001 & 0.164 & \\
\hline
\end{tabular}

Values above the diagonal line represent $\mathrm{F}_{\mathrm{ST}}$ scores. Values below diagonal line represent $\mathrm{p}$ values with bolded numbers indicating significance $(\mathrm{p}<.0022)$ after Bonferroni correction. 
Table 4. Population differentiation measured as Pairwise FST (Calculated by FSTAT 2.9.3, Goudet 2001) for populations of brook trout in the upper Shavers Fork, West Virginia, USA. Classification of culvert is through the Love and Taylor (2003) protocol.

\begin{tabular}{|c|c|c|c|c|c|c|c|c|c|c|c|}
\hline \multirow[b]{2}{*}{$\begin{array}{l}\text { Sites Classified } \\
\text { as Impassable } \\
\text { (Red) }\end{array}$} & \multicolumn{3}{|c|}{ Comparison Sites } & \multicolumn{3}{|c|}{ Comparison Sites } & \multicolumn{3}{|c|}{ Comparison Sites } & \multicolumn{2}{|c|}{ Comparison Sites } \\
\hline & $\begin{array}{l}\text { Upper } \\
\text { Rocky }\end{array}$ & $\begin{array}{l}\text { Dark Run } \\
\text { Upper }\end{array}$ & $\begin{array}{l}\text { Sites Classified as } \\
\text { Partially Passable } \\
\text { (Grey) }\end{array}$ & $\begin{array}{l}\text { Upper } \\
\text { Rocky }\end{array}$ & $\begin{array}{l}\text { Dark Run } \\
\text { Upper }\end{array}$ & $\begin{array}{l}\text { Sites classified } \\
\text { as passable } \\
\text { (Green) }\end{array}$ & $\begin{array}{l}\text { Buck } \\
\text { Middle }\end{array}$ & $\begin{array}{l}\text { Black } \\
\text { Middle }\end{array}$ & $\begin{array}{l}\text { Control } \\
\text { Sites }\end{array}$ & $\begin{array}{l}\text { Lower } \\
\text { Rocky }\end{array}$ & $\begin{array}{l}\text { Dark Run } \\
\text { Lower }\end{array}$ \\
\hline Lamothe Hollow & 0.054 & 0.064 & Spruce Upper & 0.014 & 0.022 & Buck Upper & 0.001 & - & $\begin{array}{l}\text { Upper } \\
\text { Rocky }\end{array}$ & 0.000 & - \\
\hline Oates Run & 0.023 & 0.011 & Buck Middle & 0.023 & 0.037 & Black Upper & - & 0.023 & $\begin{array}{l}\text { Dark Run } \\
\text { Upper }\end{array}$ & - & 0.000 \\
\hline Beaver Upper & 0.104 & 0.091 & & & & & & & & & \\
\hline Beaver Lower & 0.061 & 0.061 & & & & & & & & & \\
\hline
\end{tabular}

Bolded FST values indicate significance $(\mathrm{p}<.0022)$ after Bonferroni correction. 
Figure 1: Phase I, Green-Gray-Red classification filter from Love and Taylor (2003) protocol. The protocol was used in the Poplar-Jeffers et al. 2009 study and adopted for the purposes of this study.

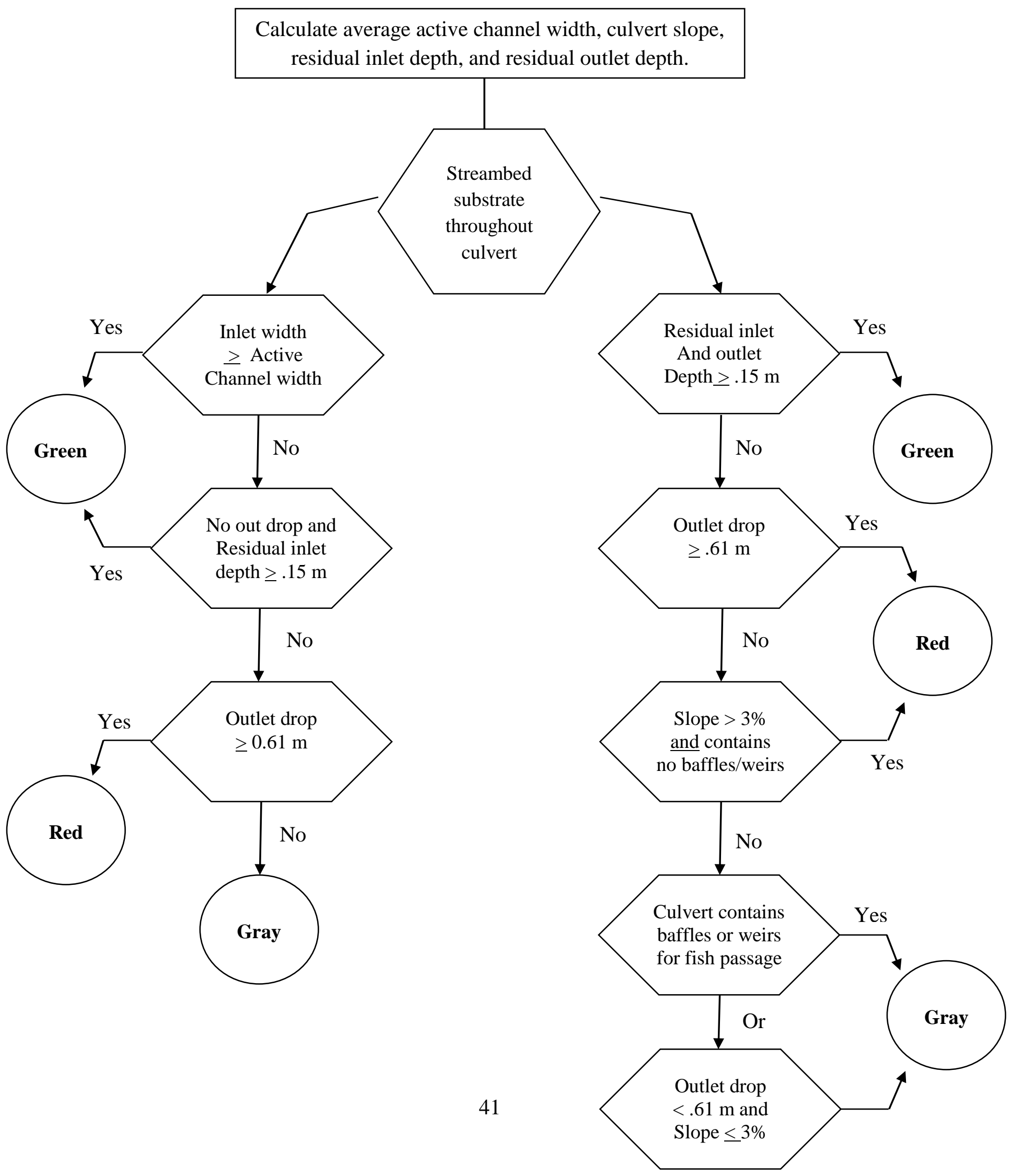


Figure 2. Map of the Upper Shavers Fork watershed, eastern West Virginia. Location of culvert is indicated by a circle and classification by through the Love and Taylor (2003) protocol is indicated by the corresponding color where red=impassable, grey=partially passable, and green=completely passable. The numbers next to circles represents the sample size.

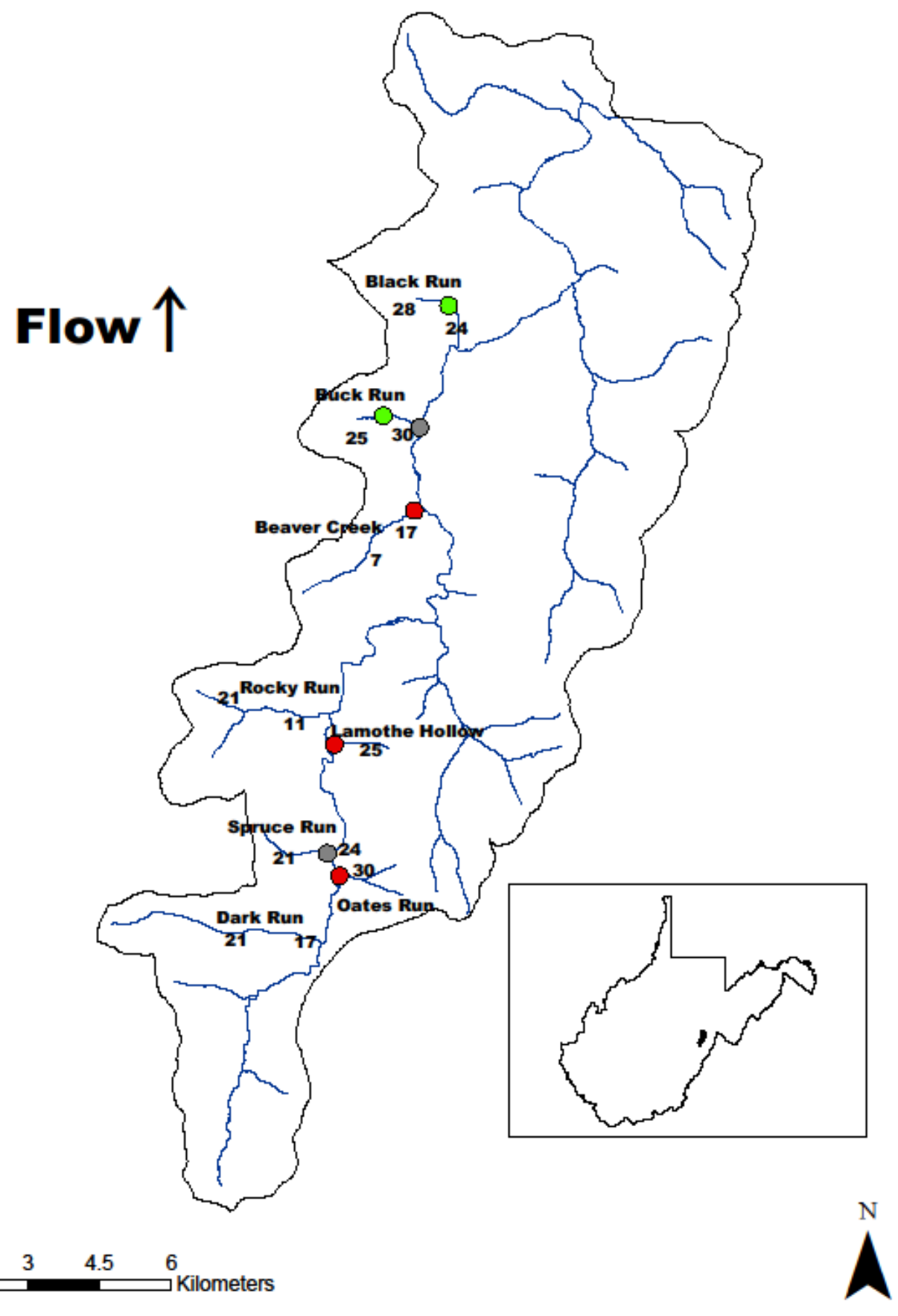


Figure 3. Mantel test of isolation by distance using swim distance between sites using genetic distance calculated in FSTAT (Goudet 2001) (Mantel $\mathrm{r}=0.23, \mathrm{p}=0.98$ )

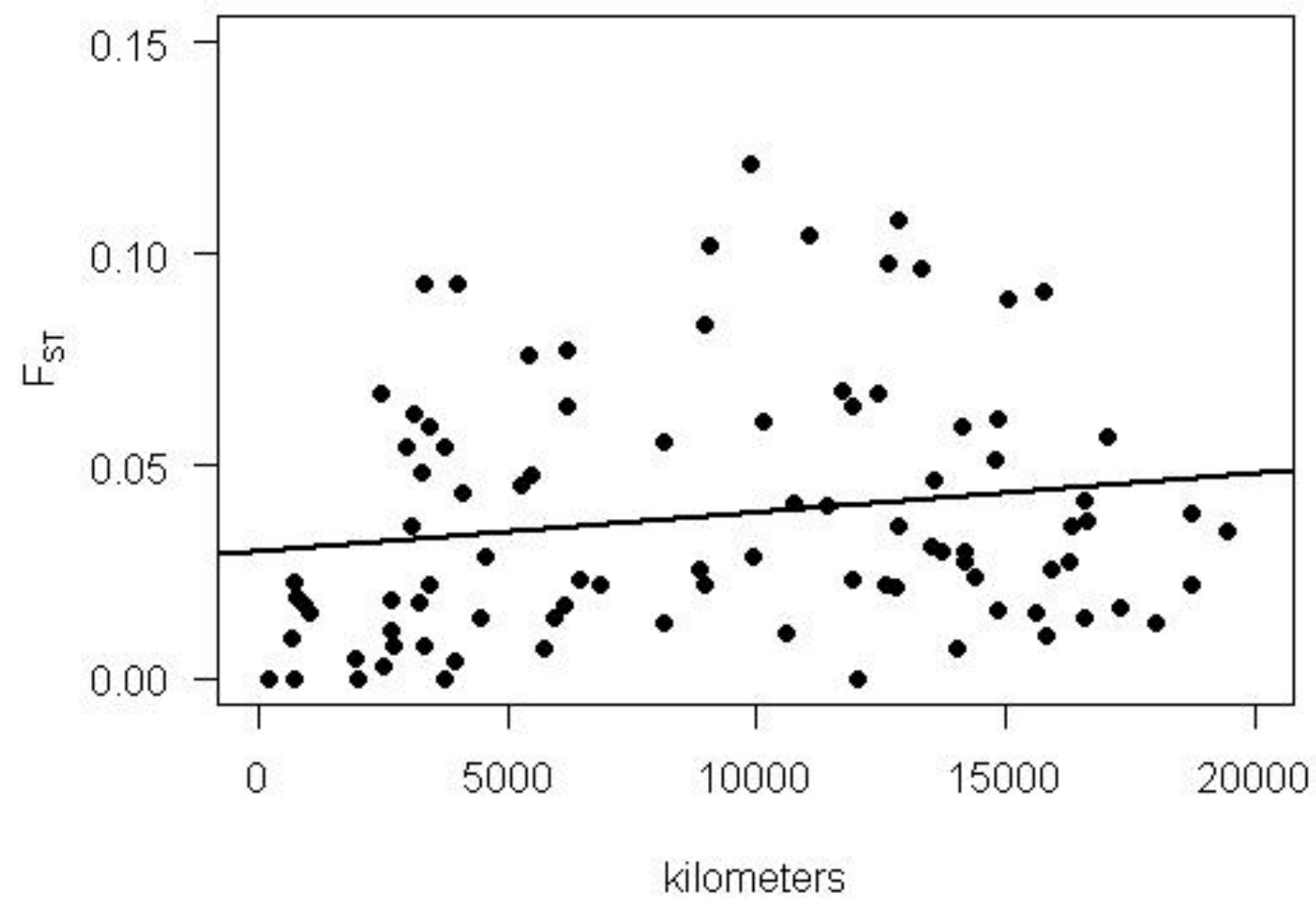


Figure 4. Plot of allelic richness $\left(R_{S}\right)$ versus basin area $\left(\mathrm{km}^{2}\right), \mathrm{R}^{2}=0.07, \mathrm{p}=0.35$. Colored circles represent each sampling site $(\mathrm{n}=14)$ along with Love and Taylor (2003) culvert classification.

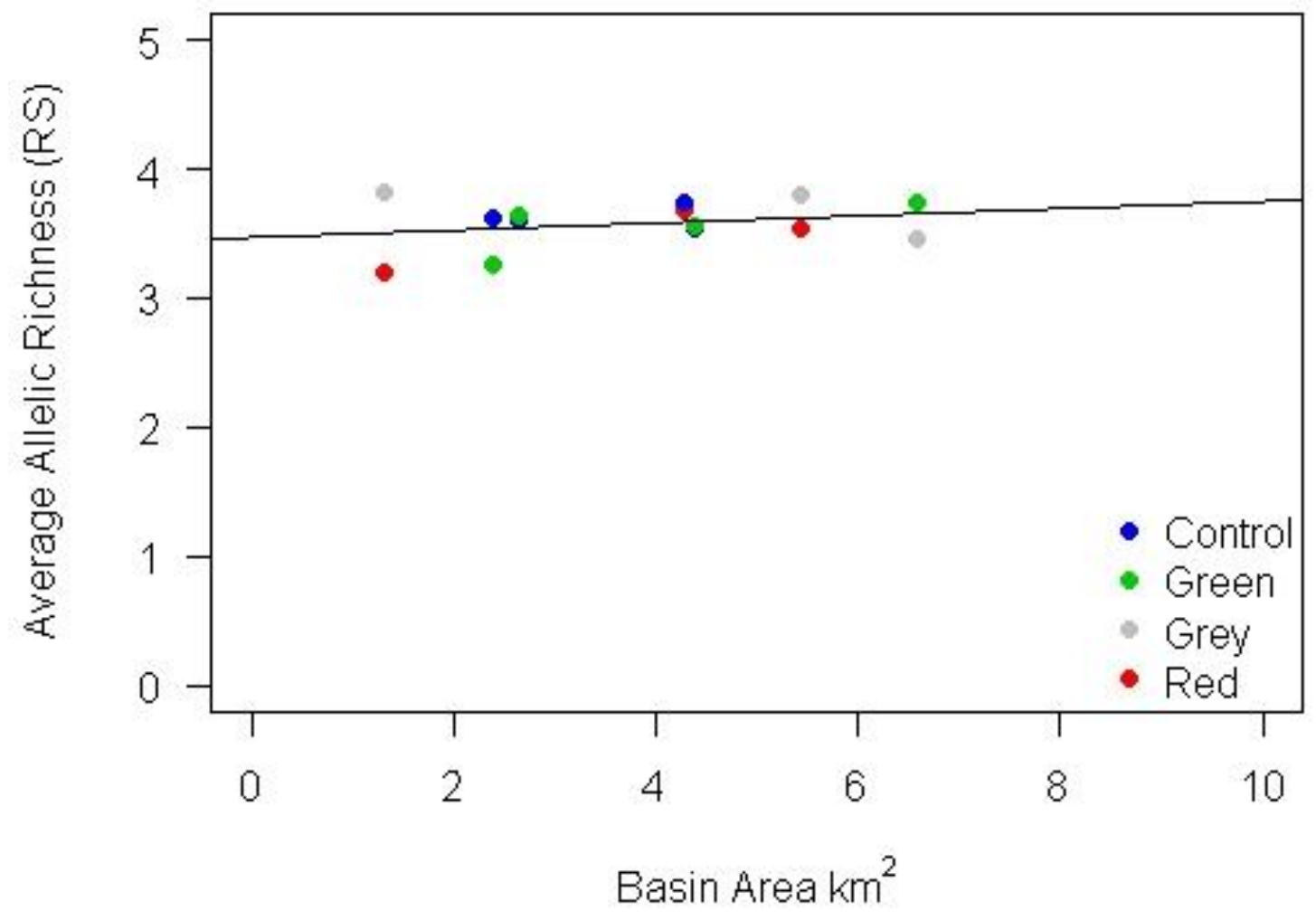


Figure 5. Natural log of likelihood plotted against the number of possible populations $K$, generated in STRUCTURE HARVESTER (Earl and vonHoldt, 2012). The length of bars indicates the variability at a given population size.

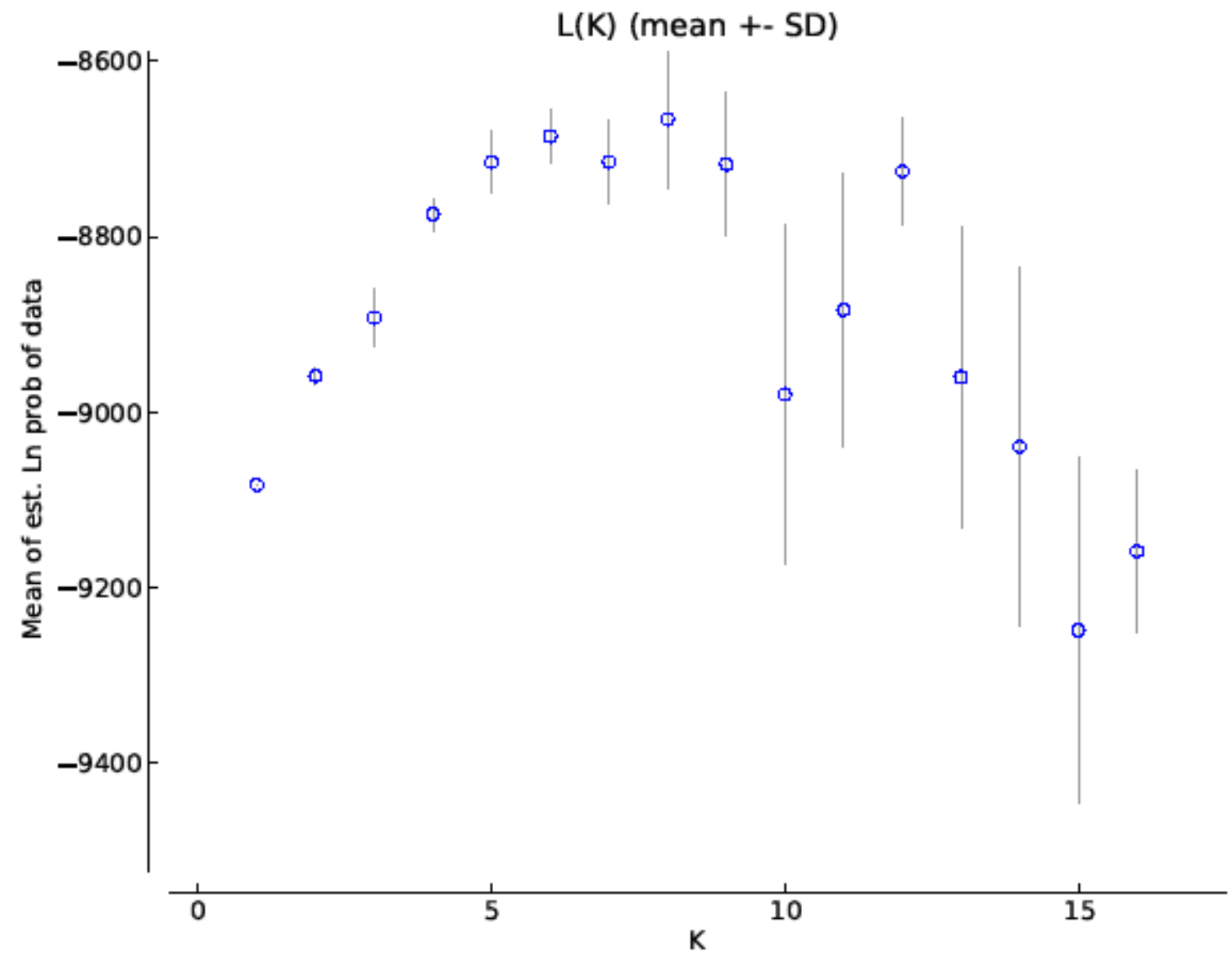


Figure 6. Number of populations indicated by $\Delta \mathrm{K}$ plot generated in STRUCTURE HARVESTER (Earl and vonHoldt, 2012). Peaks at 2 and 12 possible populations were observed.

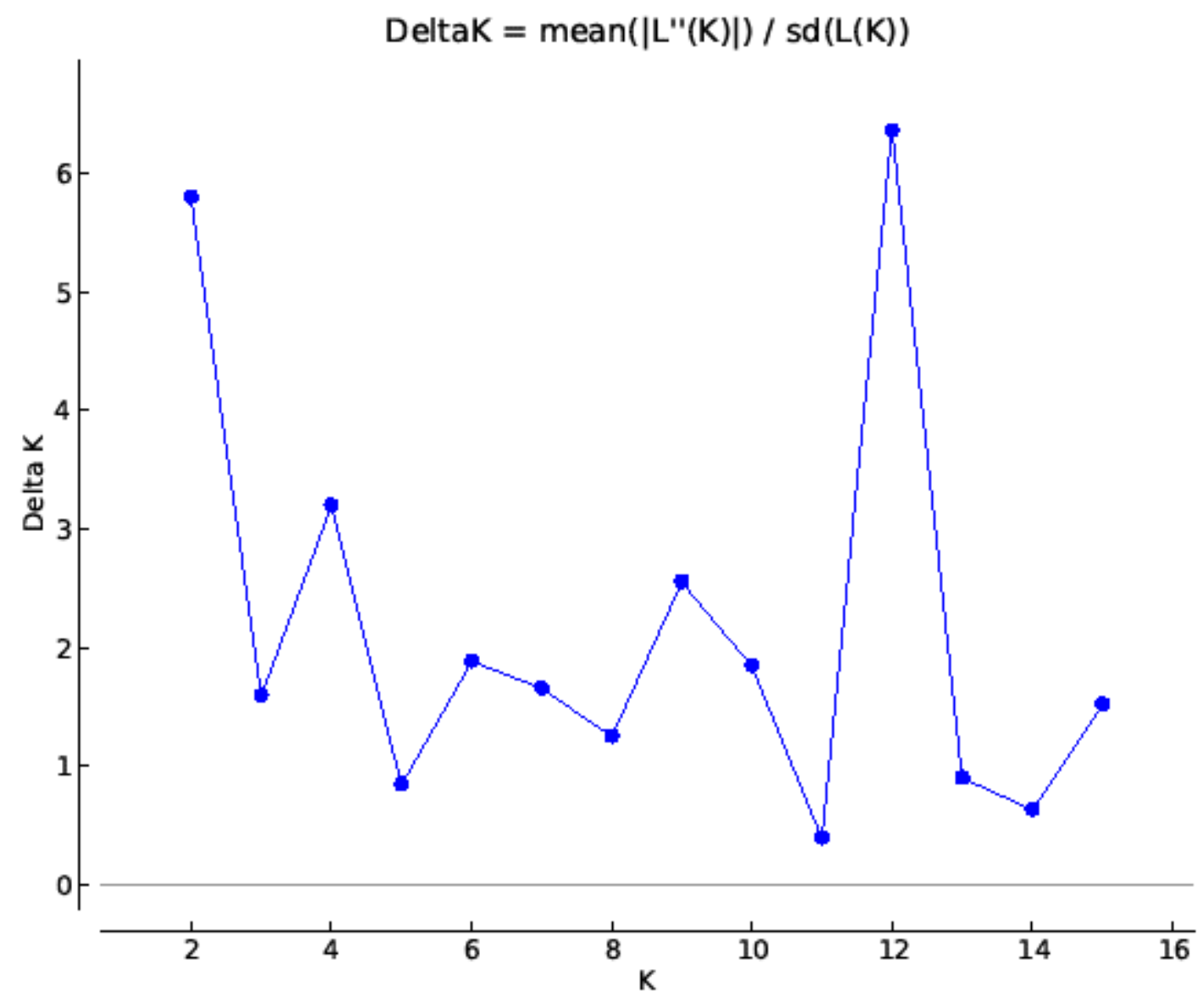


Figure 7. Structure graph of two populations without known priors when $K=4$. The $\mathrm{x}$ axis represents the sampling site where $1=\mathrm{Buck}$ Up, $2=\mathrm{Buck}$ Mid, 3=Oates Run, 4=Black Upper, 5=Black Middle, 6=Upper Rocky, 7=Lower Rocky, 8=Lamothe Hollow, 9=Spruce Lower, 10=Spruce Upper, 11=Dark Lower, 12=Dark Upper, 13=Beaver Upper, 14=Beaver Lower.

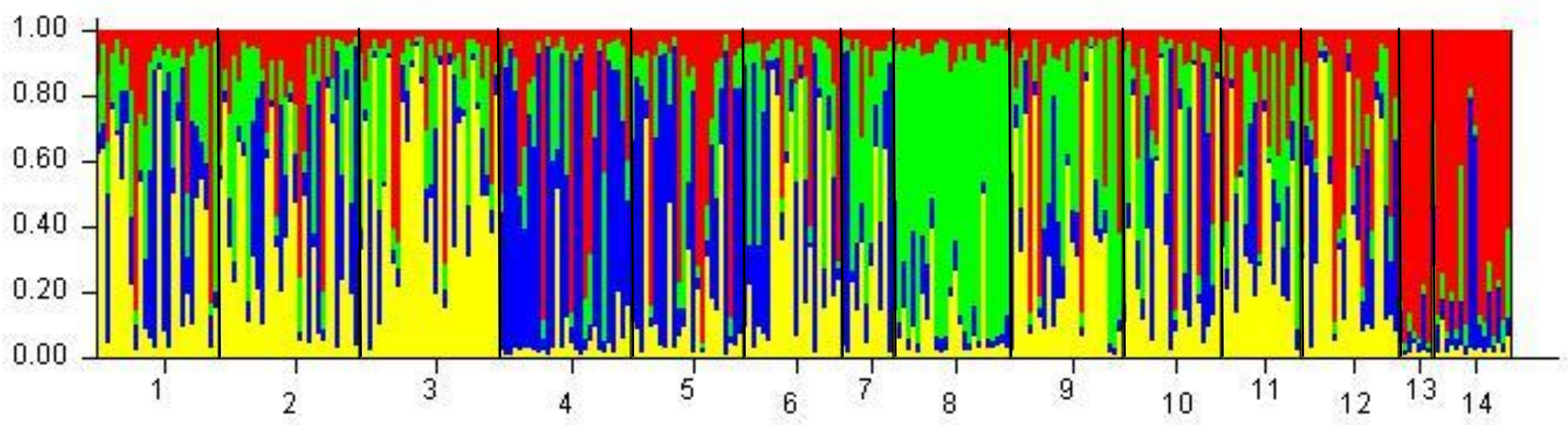


Figure 8. Natural log of likelihood plotted against the number of possible populations $K$, generated in STRUCTURE HARVESTER (Earl and vonHoldt, 2012) using sampling locations as prior information in STRUCTURE (Pritchard et al. 2000). The length of bars indicates the variability at a given population size.

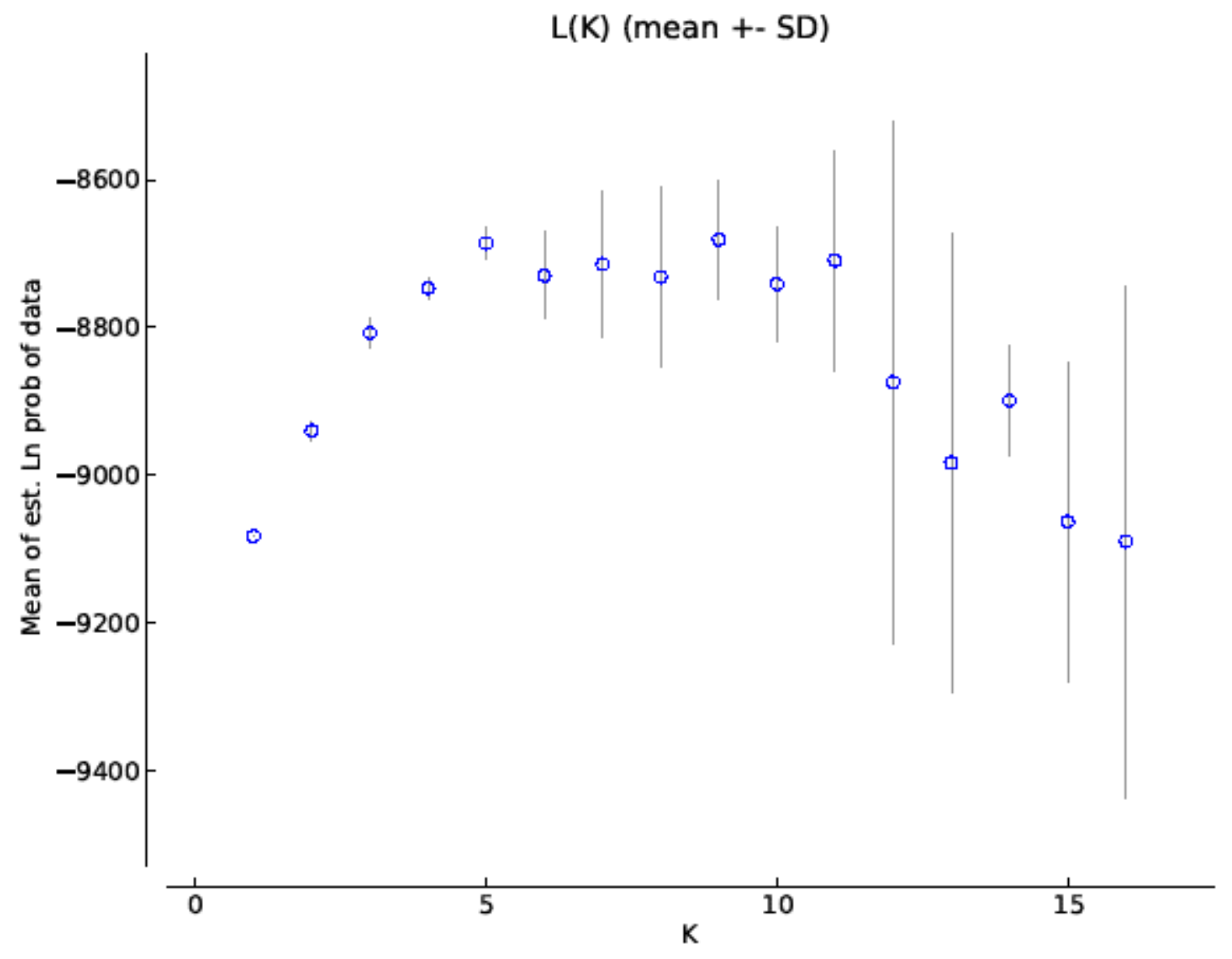


Figure 9. Change in the number of populations $(\Delta \mathrm{K})$ plot generated in STRUCTURE HARVESTER (Earl and vonHoldt, 2012) indicating the number of populations as $K=3$ or $K=5$ (Evanno et al. 2005).

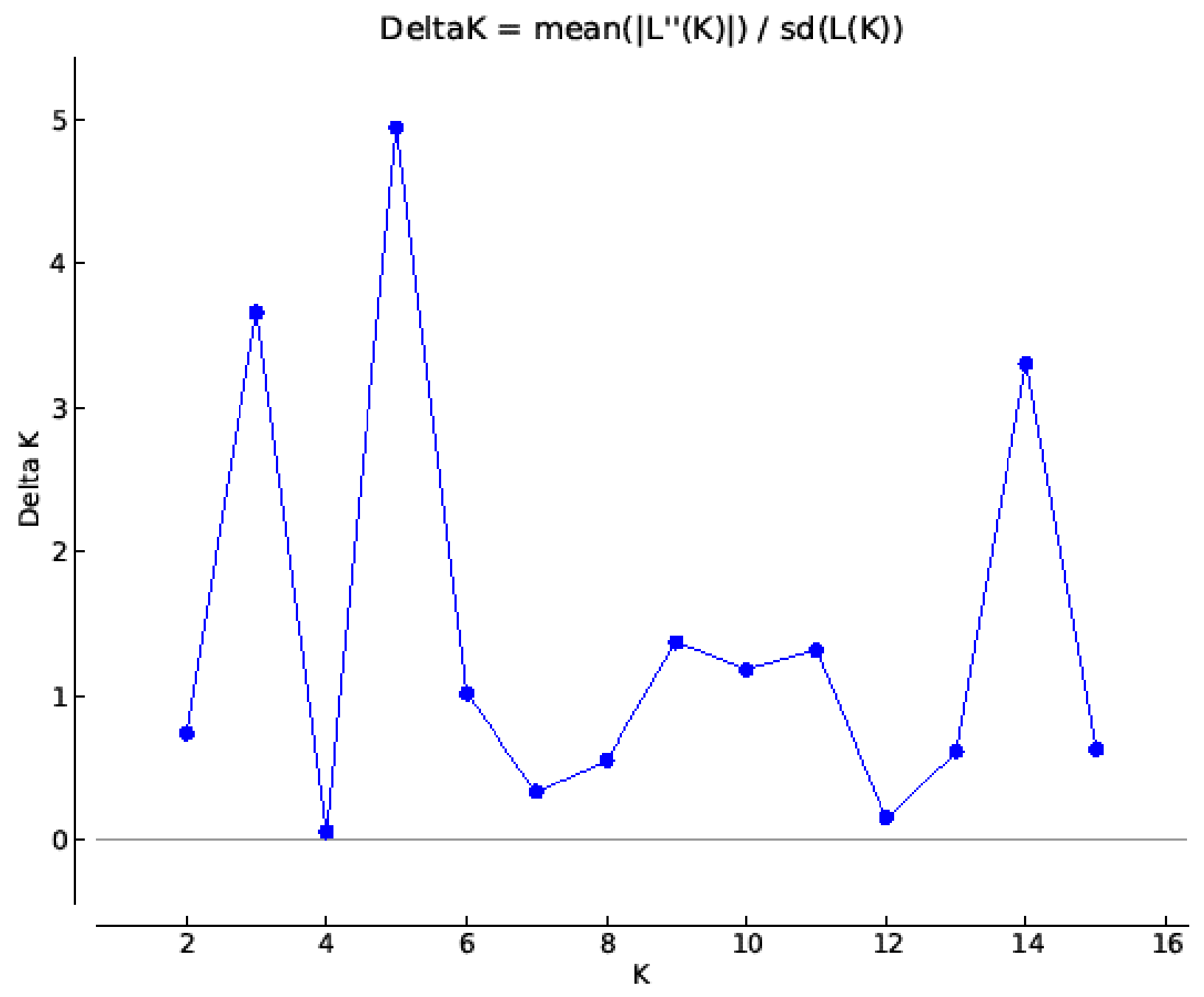


Figure 10. STRUCTURE plot after 100,000 MCMC using sampling locations as known priors, $K=5$, where 1=Buck Up, $2=$ Buck Mid, $3=$ Oates Run, 4=Black Upper, 5=Black Middle, 6=Upper Rocky, 7=Lower Rocky, 8=Lamothe Hollow, 9=Spruce Lower, 10=Spruce Upper, 11=Dark Lower, 12=Dark Upper, 13=Beaver Upper, 14=Beaver Lower.

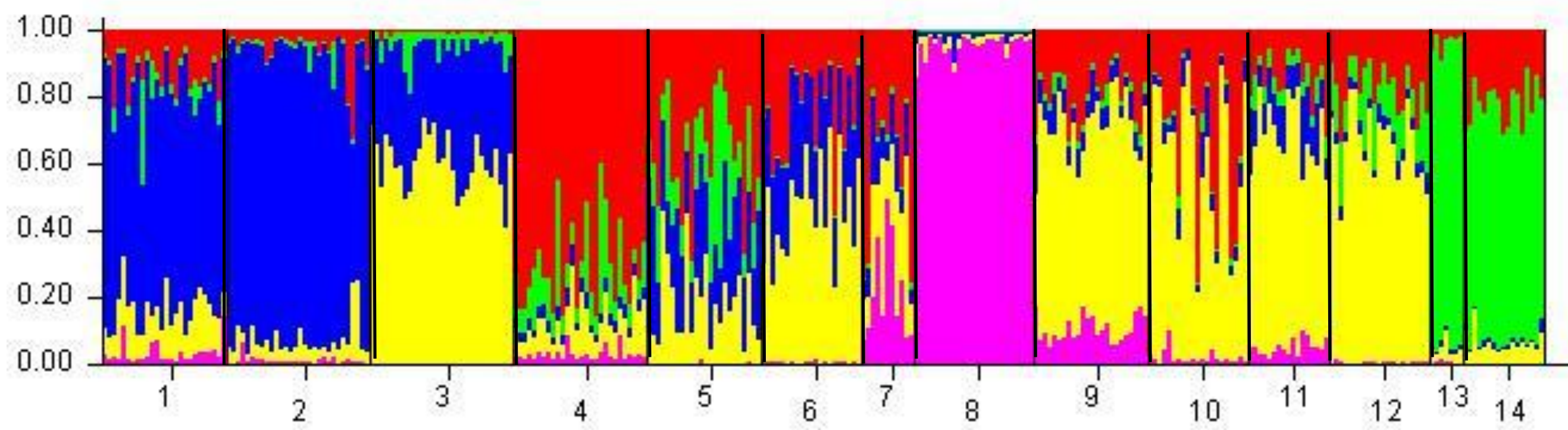


Figure 11. Phylogenetic tree of sampling locations using Cavalli-Sforza chord distance (Cavalli-Sforza and Edwards 1967). Bootstrap values (based on 1000 replicates) over 50\% are reported.

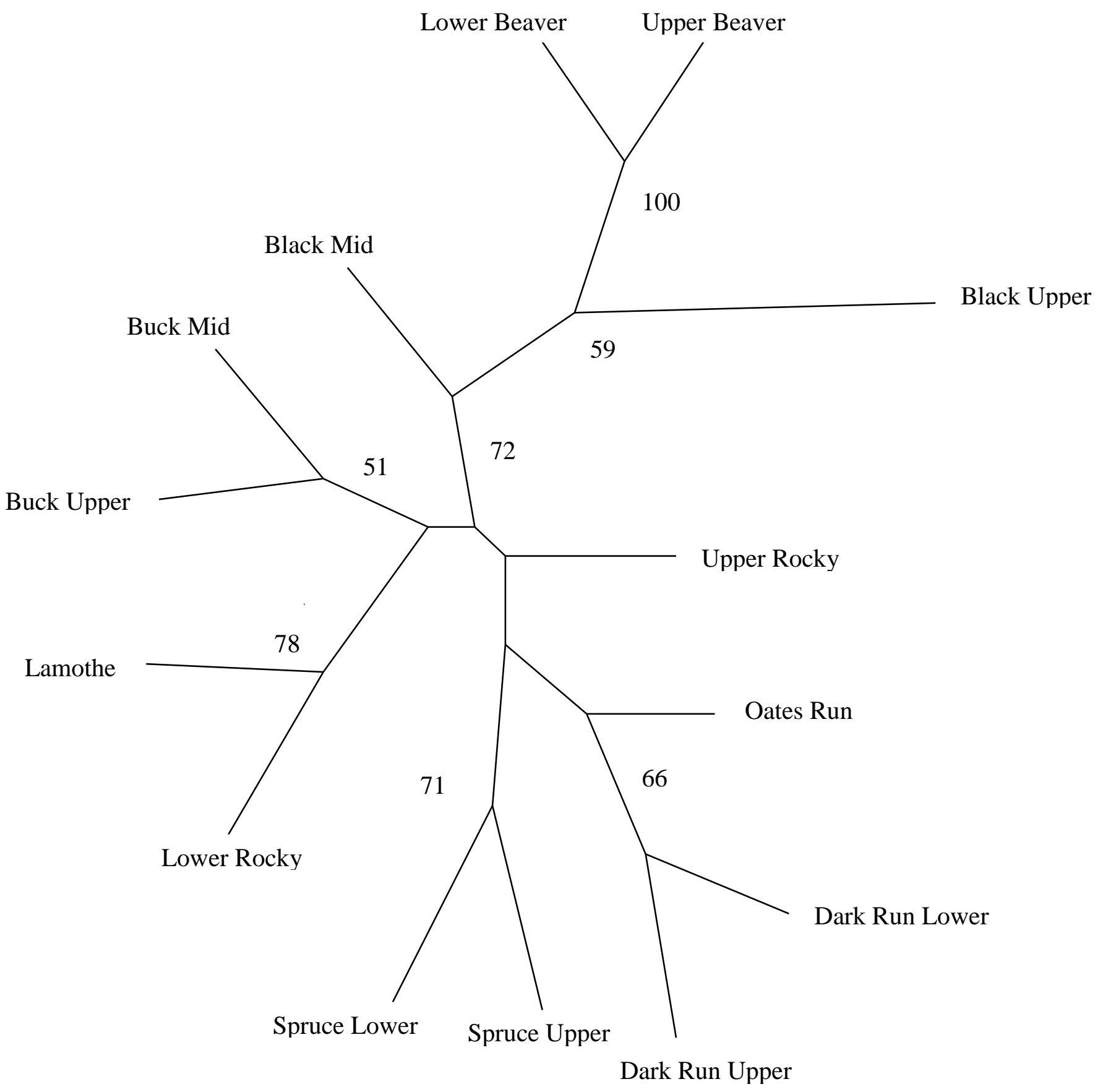


Figure 12. Results of Barrier (Manni et al. 2004) software. Polygons created using Veronoii tesselation and connectivity of sampling locations (1=Buck Up, 2=Buck Mid, 3=Oates Run, 4=Black Upper, 5=Black Middle, 6=Upper Rocky, 7=Lower Rocky, 8=Lamothe Hollow, 9=Spruce Lower, 10=Spruce Upper, 11=Dark Lower, 12=Dark Upper, 13=Beaver Upper, 14=Beaver Lower) is calculated through Monomier's maximum difference algorithm (1973). Red lines indicate barriers, with the numbers along the barriers indicating the number of bootstrap replicates (out of 1000) that support the barrier. Values reported as (>50\%) indicate signficant barriers. Signficant values were found at the Beaver Creek sampling locations (13 and 14) and Lamothe Hollow (8), both above culverts classified as impassable .

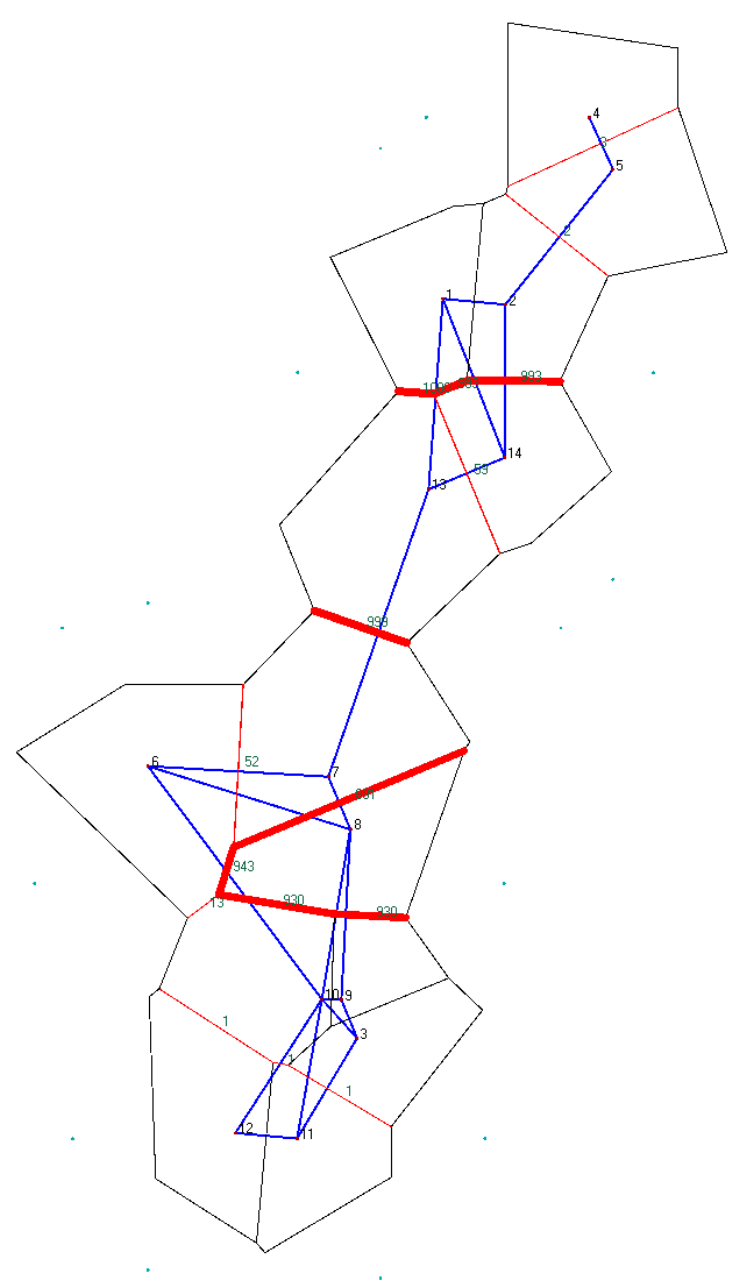




\title{
Chapter 3
}

\section{Identification of Migrants into Beaver Creek after Culvert Restoration}

\begin{abstract}
Habitat fragmentation caused by road culverts has been viewed as a threat to brook trout (Salvelinus fontinalis) population persistence. Restoration of an impassable road culvert on a second order stream (Beaver Creek) occurred in June 2011, potentially reestablishing connectivity between brook trout populations. Genetic assignment to 18 potential source populations identified 24 individuals (63\%), of which six (25\%) were found to be from source populations other than Beaver Creek within one year post restoration. The results of this study emphasize the importance of uninterrupted connection between populations and highlight the success of such restoration projects.
\end{abstract}

\section{Introduction}

Populations of brook trout (Salvelinus fontinalis) have been diminished by historical losses of habitat (Hudy et al. 2008), overharvesting, and stocking of non-native salmonids (Flebbe 1994; Marschall and Crowder 1996; Galbreath et al. 2001). In the eastern United States, especially the central Appalachians, traditional improvements to headwater streams have involved treating sources of acidification with limestone (Zurbuch 1984; Gloss et al. 1989; Clayton and Menedez 1996; Hudy et al. 2000); however there is growing concern of populations becoming patchily distributed due to habitat fragmentation (Nagel 1991; Dunham and Rieman 1999; Dunham et al. 1999; Fagan 2002; Letcher et al. 2007). 
Road culverts have been identified as sources of aquatic habitat fragmentation, (Park et al. 2008; Lamothe et al. 2009) due to conditions that include steep slopes (Poplar-Jeffers et al. 2009), insufficient water depth (Gibson et al. 2005), high outlet drop (Poplar-Jeffers et al. 2009; Burford et al. 2009; Riley 2004; MacPherson et al. 2012), increased water velocities (Gibson et al. 2009; Belford and Gould 1989), and culvert length (Bouska and Paukert 2009; Briggs and Galarwoicz 2013). Consequences of these symptoms have resulted in losses of species composition (Warren and Pardew 1998, Vander Plyum et al. 2008, Nislow et al. 2005) and loss of genetic diversity (Wofford et al. 2005, Neville et al. 2009).

Removal of dispersal barriers has been viewed as a possible solution to restore continuity to headwater stream habitats (Poplar-Jeffers et al. 2009); however, characterizing population responses to headwater stream restoration efforts is of critical importance for assessing the conditions needed for organism recovery (Kondolf 1995) and additionally evaluating the cost and benefit of each treatment (Petty and Thorn 2005). Standard assessment analyses including, catch per unit of effort (CPUE), mark and recapture, and radio telemetry have paralleled traditional stream rehabilitation efforts (e.g., Muotka et al. 2002; Stanley et al. 2007), however viewing headwater stream responses at a single scale ignores the innate complexity of riverscapes (Petty et al. 2012; Fausch et al. 2002) and the complex life history strategies brook trout employ to maximize foraging and reproductive ability (Rogers and Curry 2004; Petty et al. 2005; Utz and Hartman 2006; Hansbarger et al. 2010; Stolarski and Hartman 2010; Petty et al. 2012).

Although theoretical ecology provides a framework to predict organism response to varying environments (Levins 1969, Pulliam 1988), genetic assignment can illustrate potential fine-scale dispersal patterns of individual populations (Castric and Bernatchez 2004) to clarify 
population genetic responses to changing habitat variables within a watershed (Kanno et al. 2011). Genetic assignment has also been previously used to assign individuals to source populations to monitor migration above and below a dam (e.g., Neraas and Spruell 2001), and identify potential first generation hybrids (e.g., Sloss et al. 2008).

The objectives of this study are to assign individual migrants sampled in Beaver Creek less than one year after culvert restoration back to their source populations and examine any population structure change after culvert restoration.

\section{Methods}

Study Area

The study is located entirely in the Upper Shavers Fork watershed of the Monongahela National Forest, located in Pocahontas and Randolph counties of eastern West Virginia (Figure 1). The mainstem of the Shavers Fork watershed is a large, productive system exhibiting a significantly more diverse fish community than compared to tributaries (Bopp 2002). Brook trout residing in the Shavers Fork mainstem exhibit high daily rates of movement (50 m/day) (Petty et al. 2012) which allows for spatial linkage between populations inhabiting smaller tributaries within the same temporal scale. However, abiotic factors such as basin size and lack of suitable substrate (Petty et al. 2005) prohibit brook trout spawning in the mainstem, requiring brook trout to return to smaller, alkaline headwater streams (Petty et al. 2005).

Historically, the Upper Shavers Fork was a very productive region for brook trout; however a logging industry was established in the valley founded primarily on the abundance of red spruce, Picea rubens. Among the developments to the valley was the construction of a railroad paralleling the edge of the Shavers Fork mainstem, leading to the logging town of 
Spruce. Consequently, multiple culverts were installed under the railroad to allow hydrologic flow through them. However, due to the slope of the surrounding area, many of these culverts were installed with the culvert hanging above the bottom of the streambed, possibly cutting off dispersal for some headwater streams.

In an effort to restore movement ability to headwater streams, a culvert precluding passability due to a high outlet hang was removed at Beaver Creek in the Upper Shavers Fork, West Virginia in the summer of 2011. Restoration of the site included a replacement of the original culvert, as well as placement of continuous substrate throughout the culvert to provide instream habitat and variability of flow. Additionally, to avoid outlet hang, a series of angled log weirs provided a step-like series of pools for brook trout to gradually access the culverted section.

\section{Fish sampling and Tissue Collection}

Fourteen populations of brook trout were sampled from second and third order tributaries off of the Shavers Fork mainstem $(\mathrm{N}=268)$ during the months of June and July of 2012 and 2013 (Figure 1). Sampling for Beaver Creek post replacement occurred in June 2012 (Upper Beaver $=18$, Lower Beaver $=20$ ) while samples collected before culvert replacement occurred in June 2011(Upper Beaver =17, Lower Beaver = 7). Additional samples from a June 2006 collection $(\mathrm{N}=214)$ were included in the analysis to expand sampling area into the first fork (First) and second fork (Odey Run, Upper) of the Upper Shavers Fork watershed. Samples from 2006 were processed at the USGS lab at the Leetown Science Center and standardized for allele size designations using 16 samples. 
For all sampled sites, brook trout from multiple cohorts were collected via backpack electrofishing (Model LR-24, Smith Root, Vancouver, Washington) in a 150 meter, single upstream pass and were anesthetized using clove oil. Fin clips from the adipose and caudal fin were taken and preserved in $95 \%$ ethanol until extraction.

\section{Genetic Protocols}

For tissue samples collected in the 2012 and 2013 collections, genomic DNA was extracted by using the Wizard ${ }^{\circledR}$ SV-96 DNA purification system (Promega, Madison, WI) according to manufacturer's protocol. Extracted DNA was quantified using a spectrophotometer

(NanoDrop, Wilmington, DE) and standardized to a concentration of $10 \mathrm{ng} / \mu \mathrm{L}$. A suite of thirteen microsatellite loci described in King et al. (2012) were amplified using either a MJ Research PCT-200 or BioRad C1000 thermocycler using $10 \mu \mathrm{L}$ reactions with $2 \mu \mathrm{L}$ of DNA. The amplification protocol for loci Sfo-B52, Sfo-C79, Sfo-D100, Sfo-C24, Sfo-C28, Sfo-C115, Sfo-C113 started with an initial heating of $94^{\circ} \mathrm{C}$ and then continued with 35 cycles of $94^{\circ} \mathrm{C}$ (30 $\mathrm{sec}), 56^{\circ} \mathrm{C}(30 \mathrm{sec}), 72^{\circ} \mathrm{C}(45 \mathrm{sec})$, with a final hold of $72^{\circ} \mathrm{C}$ for 10 minutes (King et al. 2012). Loci Sfo-C86, Sfo-D91, Sfo-C38, Sfo-D100, Sfo-C88, Sfo-C129 were initially heated at $94^{\circ} \mathrm{C}$ and continued with 15 cycles of $94^{\circ} \mathrm{C}(45 \mathrm{sec}), 60^{\circ} \mathrm{C}(45 \mathrm{sec})$ with a decrease of $0.5^{\circ} \mathrm{C}$ per cycle, and $72^{\circ} \mathrm{C}(30 \mathrm{sec})$. The protocol continued for an additional 15 cycles of $94^{\circ} \mathrm{C}(45 \mathrm{sec})$, $52^{\circ} \mathrm{C}(45 \mathrm{sec})$, and $72^{\circ}$ ( $\left.30 \mathrm{sec}\right)$. Resultant fragments were genotyped using GenomeLab ${ }^{\mathrm{TM}}$ GeXP genetic analysis system (Beckman Coulter, Brea, California) and scored and checked by a single individual. 


\section{Genetic Analysis}

Each of the 20 sampling sites was treated as an individual population. Detection of possible genotyping errors or null alleles was through Micro-Checker version 2.2.3 (Van Oosterhout et al. 2004).

\section{Genetic Analysis-Assignment Testing}

The software Geneclass version 2.0 (Piry et al. 2004) was used to assign individuals from both Upper Beaver and Lower Beaver before $(\mathrm{N}=24)$ and after $(\mathrm{N}=38)$ culvert restoration using the Bayesian based methods described in Rannala and Mountain (1997). All tributary populations, including Beaver Creek before culvert replacement, were used as reference populations. Three different resampling algorithms, Paetkau et al. (2004), Cornuet et al. (1999), Rannala and Mountain (1997), were used to calculate the probabilities of assignment at a type I error rate of 0.05 using 10,000 Monte Carlo repetitions. Notable differences between all three resampling methods occur as both Paetkau et al. 2004 and Rannala and Mountain (1997) assign individuals based on an individual's genotype likelihood of a source population whereas Cornuet et al. (1999) assigns individuals based on genetic distance of individuals and source populations. However, the assumptions of the likelihood-based methods differ as the method developed by Paetkau et al. (2004) preserves linkage disequilibrium, but the approach taken by Rannala and Mountain (1997) assumes linkage equilibrium among the loci. Determination of a correct individual assignment was through assignment of the most likely source population (Berry et al. 2004) and congruency of all three resampling algorithms. 


\section{Genetic Analysis-Population Structure}

To determine the most likely number of populations $K$, the Bayesian software STRUCTURE (Pritchard et al. 2000) was implemented by testing ln likelihoods using 5 iterations of possible values for $K=1-22$ using the sampling locations as priors. Five iterations of possible values for $K=1-22$ (100,000 Burn-ins and 100,000 Monte-Carlo Markov Chain repetitions) were used and the results were imported into STRUCTURE HARVESTER (Earl and vonHoldt, 2012) to visually determine the most likely value of $K$ by examining the log likelihood of the number of populations and $\Delta K$ (Evanno et al. 2005).

\section{Results}

Using the source with the highest probability as the criteria for assignment described in Berry et al. (2004) and congruency between all three resampling algorithms, 22 individuals (92\%) from Beaver Creek before culvert replacement assigned back to their respective source population (Table 1). Of the individuals that could be assigned, all of them assigned back to their sampled location (either Upper or Lower Beaver). After culvert replacement, 24 individuals (63\%) were able to be genetically assigned to possible source populations (Table 2). Of these individuals, 18 assigned to either the Upper Beaver or Lower Beaver before culvert replacement and five of these individuals assigned to the Black Run middle location. Additionally, one individual assigned to Lambert Run.

The most likely number of populations was found to be two, $K=2$ using the log likelihood of the number of populations (Figure 2) and $\Delta K$ (Figure 3) (Evanno et al. 2005). Individuals sampled at Beaver Creek before and after culvert replacement strongly differentiated from all 
other sites (Figure 4); however the samples taken after culvert restoration at Beaver Creek had less differentiation indicating possible migration from other sources.

\section{Discussion}

This study illustrates rapid migration ( $<1$ year after removal) of brook trout within a high-elevation watershed where aquatic connectivity was restored. Genetic assignment revealed two populations, Black Run and Lambert Run, as possible sources of individual migrants after barrier removal. While the population structure remained differentiated from other streams after barrier removal, the indication of several individual migrants illustrates a future population structure that could be potentially comparable to other streams within the watershed, pending individuals from other source populations continue to disperse into Beaver Creek.

A previous study by Roghair and Dolloff (2005) examined brook trout colonization movements into an entirely defaunated stream and found partial colonization within one year. This study concurs with the Roghair and Doloff (2005) findings as migration was found to occur within one after restoration. However, this study found dispersal from other source populations into an inhabited stream after connectivity was restored. Additionally, the Roghair and Dolloff study (2005) could be used as a model for continued effort to monitor migration into Beaver Creek as complete stream colonization did not occur until three years after extirpation.

This finding of dispersal and individual migration from other streams emphasizes the importance of species management at an appropriate scale (Fausch et al. 2002; Petty et al. 2012). Although measuring success at a single scale provides information of the chemical, physical and biological conditions needed for restoration success, understanding the response within a large scale watershed helps clarify the complexity of the system. Additionally, these findings suggest 
that the Upper Shavers Fork exists as a possible metapopulation where spatiotemporal extinction requires movements from neighboring habitat patches for population persistence (Levins 1969; Hanski et al. 1995; Hanski 1999). Although brook trout were found to inhabit Beaver Creek prior to culvert restoration, restoring connectivity between habitat patches is important for population persistence as spatially isolated populations, as a result of movement barriers, are subjected to greater population extinction risk (Nagel 1999; Dunham and Rieman 1999; Fagan 2002; Letcher et al. 2007).

The rapid success of this project, measured by migration of individuals from other populations, suggests that additional restoration of impassable culverts should continue in order to reconnect highly-reproductive, headwater stream habitats for continued brook trout persistence (Poplar-Jeffers et al. 2009). Additionally, while economics often limit the number and design of restoration projects, measuring rehabilitation progress needs to occur at an appropriate scale for future management considerations. 


\section{Literature Cited}

Berry, O., M. D. Tocher, and S. D. Sarre. 2004. Can assignment tests measure dispersal? Molecular Ecology 13: 551-561.

Bouska, W. W., and C. P. Paukert. 2009. Road crossing designs and their impact on fish assemblages of great plains stream. Transactions of the American Fisheries Society 139: 214-222.

Briggs, A. S., and T. L. Galarowicz. 2013. Fish passage through culverts in central Michigan warmwater streams. North American Journal of Fisheries Management 33: 652-664.

Bopp, J. 2002. The combined effects of water chemistry, canopy cover, and basin area on benthic macroinvertebrates along a central Appalachian stream continuum. Master's thesis. West Virginia University, Morgantown.

Burford, D. D., T. E. McMahon, J. E. Cahoon, and M. Blank. 2009. Assessment of trout passage through culverts in a large Montana drainage during summer low flow. North American Journal of Fisheries Management 29: 739-752.

Castric, V., and L. Bernatchez. 2004. Individual assignment test reveals differential restriction to dispersal between two salmonids despite no increase of genetic differences with distance. Molecular Ecology 13:1299-1312.

Cavalli-Sforza, L. L., and A. W. F. Edwards. 1967. Phylogenetic analysis: models and estimation procedures. Evolution 21: 550-570.

Clayton, J. L., E. S. Dannaway, R. Menendez, H. W. Rauch, J. J. Renton, S. M. Sherlock, and P. E. Zurbuch. 1998. Application of limestone to restore fish communities in acidified streams. North American Journal of Fisheries Management 18: 347-360.

Cornuet J. M., S. Piry, G. Luikart, A. Estoup, M. Solignac. 1999. New methods employing multilocus genotypes to select or exclude populations as origins of individuals. Genetics 153:1989-2000.

Dunham, J. B., and B. E. Rieman. 1999. Metapopulation structure of bull trout: influences of physical, biotic, and geometrical landscape characteristics. Ecological Applications 9: 642-655.

Dunham, J. B., G. L. Vinyard, and B. E. Rieman. 1997. Habitat fragmentation and extinction risk of Lahontan cutthroat trout. North American Journal of Fisheries Management 17: 11261133.

Earl, D.A., and B. M. vonHoldt. 2012. STRUCTURE HARVESTER: a website and program for visualizing STRUCTURE and implementing the Evanno method. Conservation Genetics Resources 4: 359:361. 
Fagan, W. F. 2002. Connectivity, fragmentation and extinction risk in dendritic metapopulations. Ecological Society of America 83: 3243-3249.

Fausch, K. D., C. E. Torgersen, C. V. Baxter, and H. W. Li. 2002. Landscape to riverscapes: bridging the gap between research and conservation of stream fishes. Bioscience 52: 483497.

Galbreath, P.F., N. D. Adams, S. Z. Guffey, C. J. Moore, and J. L. West. 2001. Persistence of native southern Appalachian Mountains of North Carolina and Virginia. North American Journal of Fisheries Management 21:927-934.

Gloss, S. P., C. L. Schofield, R. L. Spateholts, and B. A. Plonski. 1989. Survival, growth, reproduction, and diet of brook trout (Salvelinus fontinalis) stocked into lakes after liming to mitigate acidity. Canadian Journal of Fisheries and Aquatic Sciences 46: 277286.

Hansbarger, J. L., J. T. Petty, and P. M. Mazik. 2010. Brook Trout Movement within a highelevation watershed: consequences for watershed restoration. Proceedings from the Conference on the Ecology and Management of High-Elevation Forests in the Central and Southern Appalachian Mountains. 74-84.

Hankski, I. 1999. Habitat connectivity, habitat continuity, and metapopulations in dynamic landscapes. Oikos 87: 209-219.

Hanski, I., T. Pakkala, M. Kuussaari, and G. Lei. 1995. Metapopulation persistence of an endangered butterfly in a fragmented landscape. Oikos 72: 21-28.

Hudy, M., D. M. Downey, and D. W. Bowman. 2000. Successful restoration of an acidified stream through mitigation with limestone sand. North American Journal of Fisheries Management $20: 453-466$.

Kanno, Y., J, C. Vokoun, and B. H. Letcher. 2011. Fine-scale population structure and riverscape genetics of brook trout (Salvelinus fontinalis) distributed continuously along headwater channel networks. Molecular Ecology 20: 3711-3729.

Kondolf, G. Mathias. 1995. Five elements for effective evaluation of stream restoration. Restoration Ecology 3: 133-136.

Larson, G. L., and S. E. Moore. 1985. Encroachment of exotic rainbow trout into stream populations of native brook trout in the southern Appalachian mountains. Transactions of the American Fisheries Society 114: 195-203.

Letcher, B.H., K. H. Nislow, J. A. Coombs, M. J. O’Donnell, and T. L. Dubreuil. 2007. Population response to habitat fragmentation in a stream-dwelling brook trout population. Plos One 2: 1-11. 
Levins, R. 1969. Some demographic and genetic consequences of environmental heterogeneity for biological control. Bulletin of the Entomological Society of America 15: 237-240.

Marschall, E. A., and L. B. Crowder. 1996. Assessing population responses to multiple anthropogenic effects: a case study with brook trout. Ecological Applications 6(1): 152167.

MacPherson, L. M., M. G. Sullivan, A. L. Foote, and C. E. Stevens. 2012. Effects of culverts on stream fish assemblages in the Alberta foothills. North American Journal of Fisheries Management 32: 480-490.

Neraas, L. P., and P. Spruell. 2001. Fragmentation of riverine systems: the genetic effects of dams on bull trout (Salvelinus confluentus) in the Clark Fork River system. Molecular Ecology 10:1153-1164.

Nagel, J.W. 1991. Is the decline of brook trout in the southern Appalachians resulting from competitive exclusion and/or extinction due to habitat fragmentation? Journal of the Tennessee Academy of Science 66:141-143.

Neville, H., J. Dunham, A. Rosenberger, J. Umek, and B. Nelson. 2009. Influences of wildfire, habitat size, and connectivity on trout in headwater streams revealed by patterns of genetic diversity. Transactions of the American Fisheries Society 138:1314-1327.

Nislow, K. H., M. Hudy, B. H. Letcher, and E. P. Smith. 2011. Variation in local abundance and species richness of stream fishes in relation to dispersal barriers: implications for management and conservation. Freshwater Biology 56: 2135-2144.

Park, D., M. Sullivan., E. Bayne., and G. Scrimgeour. 2008. Landscape-level stream fragmentation caused by hanging culverts along roads in Alberts's boreal forest. Canadian Journal of Forestry Research 38: 566-575.

Paetkau, D., R. Slade, M. Burden, and A. Estoup. 2004 Direct, real-time estimation of migration rate using assignment methods: a simulation-based exploration of accuracy and power. Molecular Ecology 13:55-65.

Pritchard, J. K., M. Stephends, and P. Donnelly. 2000. Inference of population structure using multilocus genotype data. Genetics 155: 945-959.

Petty, J. P., and D. Thorne. 2005. An ecologically based approach to identifying restoration priorities in an acid-impacted watershed. Restoration Ecology 13: 348-357.

Petty. J. T., P. J. Lamothe, and P. M. Mazik. 2005. Spatial and seasonal dynamics of brook Trout populations inhabiting a central Appalachian watershed. Transactions of the American Fisheries Society 134:572-587. 
Petty, J. T., J. L. Hansbarger, and B. M. Huntsman. 2012. Brook trout movement in response to temperature, flow and thermal refugia within a complex Appalachian riverscape. Transactions of the American Fisheries Society 141: 1060-1073.

Piry S., A. Alapetite, J. M. Cornuet, D. Paetkau, L. Baudouin, and A. Estoup. 2004 GeneClass2: A software for genetic assignment and first-generation migrant detection. Journal of Heredity 95:536-539.

Pulliam, H. R. 1988. Sources, sinks, and population regulation. The American Naturalist 132: 652-661.

Poplar-Jeffers, I. O., J. T. Petty, J. T. Anderson, S. J. Kite, M. P. Strager, and R. H Fortney. 2009. Culvert replacement and stream habitat restoration: implications from brook trout management in an Appalachian watershed, U.S.A. Restoration Ecology 17: 404-413.

Rannala B., and J. L. Mountain. 1997. Detecting immigration by using multilocus genotypes. Proceedings of the National Academy of Sciences USA 94:9197-9201.

Rogers, S. M., and R. A. Curry. 2004. Genetic population structure of brook trout inhabiting a larger river watershed. Transactions of the American Fisheries Society 133:1138-1149.

Roghair, C. N., and C. A. Dolloff. 2005. Brook trout movement during and after recolonization of a naturally defaunated stream reach. North American Journal of Fisheries Management 25:777-784.

Sloss, B. L., M. J. Jennings, R. Franckowiak, and D. M. Pratt. 2008. Genetic identity of brook trout in Lake Superior South Shore streams: potential for genetic monitoring of stocking and rehabilitation efforts. Transactions of the American Fisheries Society 137:1244-1251.

Stanley, E. H., M. J. Catalano, N. Mercado-Silva, and C. H. Orr. 2007. Effects of dam removal on brook trout in a Wisconsin stream. River Research and Applications 23:792-798.

Utz, R.M., and K. J. Hartman. 2006. Termporal and spatial variation in the energy intake of brook trout (Salvelinus fontinalis) population in an Appalachian watershed. Canadian Journal of Fisheries and Aquatic Sciences 63: 2675-2686.

Vander Pluym, J. L., D. B. Eggleston, and J. F. Levine. 2008. Impacts of road crossings on fish movement and community structure. Journal of Freshwater Ecology 23:565-574.

Warren, Jr. M. L., and M. G. Pardew. 1998. Road crossings as barriers to small-stream fish movement. Transactions of the American Fisheries Society 127: 637-644.

Wigington, P. J., Jr., J. P. Baker, D. R. D. R. DeWalle, W. A. Kretser, P. S. Murdoch, H. A. Simonin, J. Van Sickle, M. K. McDowell, D. V. Peck, and W. R. Barchet. 1996. Episodic acidification of small streams in the northeast United States: episodic response project. Ecological Applications 6:374-388. 
Wofford, J. E. B., R. E. Gresswell, and M. A. Banks. 2005. Influence of barriers to movement on within-watershed genetic variation of coastal cutthroat trout. Ecological Applications 15: 628-637.

Van Oosterhout, C., W. F. Hutchinson. D. P. M. Willis, and P. Shipley. 2004. MICROCHECKER: software for identifying and correcting genotyping errors in microsatellite data. Molecular Ecology Notes 4:535-538.

Zurbuch, P. E. 1984. Neutralization of acidified streams in West Virginia. Fisheries 9: 42-47. 
Table 1. Genetic assignment of Beaver Creek individuals sampled before culvert restoration. Bold letters indicate congruency between all three sampling algorithms used in Geneclass 2.0 (Piry et al. 2002).

\begin{tabular}{|c|c|c|c|c|c|c|}
\hline $\begin{array}{l}\text { Individuals to be } \\
\text { reassigned }\end{array}$ & $\begin{array}{c}\text { Population } \\
\text { Assigned } \\
\text { (Corneut et al. } \\
\text { 1999) }\end{array}$ & Probability & $\begin{array}{c}\text { Population } \\
\text { Assigned } \\
\text { (Petkau et al. } \\
\text { 2004) }\end{array}$ & Probability & $\begin{array}{c}\text { Population } \\
\text { Assigned } \\
\text { (Rannala and } \\
\text { Mountain 1997) }\end{array}$ & Probability \\
\hline $\begin{array}{l}\text { Beaver Upper } \\
\text { Before YOY III }\end{array}$ & $\begin{array}{c}\text { Beaver Lower } \\
\text { Before }\end{array}$ & 0.54 & $\begin{array}{c}\text { Beaver Lower } \\
\text { Before }\end{array}$ & 0.77 & $\begin{array}{c}\text { Beaver Upper } \\
\text { Before }\end{array}$ & 0.60 \\
\hline $\begin{array}{l}\text { Beaver Upper } \\
\text { Before YOY II }\end{array}$ & $\begin{array}{c}\text { Beaver Upper } \\
\text { Before }\end{array}$ & 0.23 & $\begin{array}{c}\text { Beaver Upper } \\
\text { Before }\end{array}$ & 0.63 & $\begin{array}{c}\text { Beaver Upper } \\
\text { Before }\end{array}$ & 0.34 \\
\hline $\begin{array}{l}\text { Beaver Upper } \\
\text { Before YOY I }\end{array}$ & $\begin{array}{c}\text { Beaver Upper } \\
\text { Before }\end{array}$ & 0.41 & $\begin{array}{c}\text { Beaver Upper } \\
\text { Before }\end{array}$ & 0.72 & $\begin{array}{c}\text { Beaver Upper } \\
\text { Before }\end{array}$ & 0.53 \\
\hline $\begin{array}{l}\text { Beaver Upper } \\
\text { Before H13 }\end{array}$ & $\begin{array}{c}\text { Beaver Upper } \\
\text { Before }\end{array}$ & 0.66 & $\begin{array}{c}\text { Beaver Upper } \\
\text { Before }\end{array}$ & 0.83 & $\begin{array}{c}\text { Beaver Upper } \\
\text { Before }\end{array}$ & 0.75 \\
\hline $\begin{array}{l}\text { Beaver Upper } \\
\text { Before H12 }\end{array}$ & $\begin{array}{c}\text { Beaver Upper } \\
\text { Before }\end{array}$ & 0.68 & $\begin{array}{c}\text { Beaver Upper } \\
\text { Before }\end{array}$ & 0.83 & $\begin{array}{c}\text { Beaver Upper } \\
\text { Before }\end{array}$ & 0.77 \\
\hline $\begin{array}{l}\text { Beaver Upper } \\
\text { Before H11 }\end{array}$ & $\begin{array}{c}\text { Beaver Upper } \\
\text { Before }\end{array}$ & 0.67 & $\begin{array}{c}\text { Beaver Upper } \\
\text { Before }\end{array}$ & 0.84 & $\begin{array}{c}\text { Beaver Upper } \\
\text { Before }\end{array}$ & 0.76 \\
\hline $\begin{array}{l}\text { Beaver Upper } \\
\text { Before H10 }\end{array}$ & $\begin{array}{c}\text { Beaver Upper } \\
\text { Before }\end{array}$ & 0.16 & $\begin{array}{c}\text { Beaver Upper } \\
\text { Before }\end{array}$ & 0.57 & $\begin{array}{c}\text { Beaver Upper } \\
\text { Before }\end{array}$ & 0.23 \\
\hline $\begin{array}{l}\text { Beaver Lower } \\
\text { Before YOY VII }\end{array}$ & Black Mid & 0.88 & Spruce Upper & 0.99 & $\begin{array}{l}\text { Beaver Upper } \\
\text { Before }\end{array}$ & 0.89 \\
\hline $\begin{array}{l}\text { Beaver Lower } \\
\text { Before YOY VI }\end{array}$ & $\begin{array}{c}\text { Beaver Lower } \\
\text { Before }\end{array}$ & 0.09 & $\begin{array}{c}\text { Beaver Lower } \\
\text { Before }\end{array}$ & 0.37 & $\begin{array}{c}\text { Beaver Lower } \\
\text { Before }\end{array}$ & 0.14 \\
\hline $\begin{array}{l}\text { Beaver Lower } \\
\text { Before YOY V }\end{array}$ & $\begin{array}{c}\text { Beaver Lower } \\
\text { Before }\end{array}$ & 0.69 & $\begin{array}{c}\text { Beaver Lower } \\
\text { Before }\end{array}$ & 0.85 & $\begin{array}{c}\text { Beaver Lower } \\
\text { Before }\end{array}$ & 0.74 \\
\hline $\begin{array}{l}\text { Beaver Lower } \\
\text { Before YOY IV }\end{array}$ & $\begin{array}{c}\text { Beaver Lower } \\
\text { Before }\end{array}$ & 0.64 & $\begin{array}{c}\text { Beaver Lower } \\
\text { Before }\end{array}$ & 0.83 & $\begin{array}{c}\text { Beaver Lower } \\
\text { Before }\end{array}$ & 0.71 \\
\hline $\begin{array}{l}\text { Beaver Lower } \\
\text { Before YOY III }\end{array}$ & $\begin{array}{c}\text { Beaver Lower } \\
\text { Before }\end{array}$ & 0.03 & $\begin{array}{c}\text { Beaver Lower } \\
\text { Before }\end{array}$ & 0.16 & $\begin{array}{c}\text { Beaver Lower } \\
\text { Before }\end{array}$ & 0.05 \\
\hline $\begin{array}{l}\text { Beaver Lower } \\
\text { Before YOY II }\end{array}$ & $\begin{array}{c}\text { Beaver Lower } \\
\text { Before }\end{array}$ & 0.49 & $\begin{array}{c}\text { Beaver Lower } \\
\text { Before }\end{array}$ & 0.74 & $\begin{array}{c}\text { Beaver Lower } \\
\text { Before }\end{array}$ & 0.55 \\
\hline
\end{tabular}




\begin{tabular}{|c|c|c|c|c|c|c|}
\hline $\begin{array}{l}\text { Beaver Lower } \\
\text { Before YOY II }\end{array}$ & $\begin{array}{c}\text { Beaver Lower } \\
\text { Before }\end{array}$ & 0.56 & $\begin{array}{c}\text { Beaver Lower } \\
\text { Before }\end{array}$ & 0.78 & $\begin{array}{c}\text { Beaver Lower } \\
\text { Before }\end{array}$ & 0.62 \\
\hline $\begin{array}{l}\text { Beaver Lower } \\
\text { Before H09 }\end{array}$ & $\begin{array}{c}\text { Beaver Lower } \\
\text { Before }\end{array}$ & 0.26 & $\begin{array}{c}\text { Beaver Lower } \\
\text { Before }\end{array}$ & 0.58 & $\begin{array}{c}\text { Beaver Lower } \\
\text { Before }\end{array}$ & 0.33 \\
\hline $\begin{array}{l}\text { Beaver Lower } \\
\text { Before H08 }\end{array}$ & $\begin{array}{c}\text { Beaver Lower } \\
\text { Before }\end{array}$ & 0.87 & $\begin{array}{c}\text { Beaver Lower } \\
\text { Before }\end{array}$ & 0.94 & $\begin{array}{c}\text { Beaver Lower } \\
\text { Before }\end{array}$ & 0.89 \\
\hline $\begin{array}{l}\text { Beaver Lower } \\
\text { Before H07 }\end{array}$ & $\begin{array}{c}\text { Beaver Lower } \\
\text { Before }\end{array}$ & 0.13 & $\begin{array}{c}\text { Beaver Lower } \\
\text { Before }\end{array}$ & 0.43 & $\begin{array}{c}\text { Beaver Lower } \\
\text { Before }\end{array}$ & 0.18 \\
\hline $\begin{array}{l}\text { Beaver Lower } \\
\text { Before H06 }\end{array}$ & $\begin{array}{c}\text { Beaver Lower } \\
\text { Before }\end{array}$ & 0.51 & $\begin{array}{c}\text { Beaver Lower } \\
\text { Before }\end{array}$ & 0.76 & $\begin{array}{c}\text { Beaver Lower } \\
\text { Before }\end{array}$ & 0.58 \\
\hline $\begin{array}{l}\text { Beaver Lower } \\
\text { Before H05 }\end{array}$ & $\begin{array}{c}\text { Beaver Lower } \\
\text { Before }\end{array}$ & 0.65 & $\begin{array}{c}\text { Beaver Lower } \\
\text { Before }\end{array}$ & 0.83 & $\begin{array}{c}\text { Beaver Lower } \\
\text { Before }\end{array}$ & 0.71 \\
\hline $\begin{array}{l}\text { Beaver Lower } \\
\text { Before H04 }\end{array}$ & $\begin{array}{c}\text { Beaver Lower } \\
\text { Before }\end{array}$ & 0.43 & $\begin{array}{c}\text { Beaver Lower } \\
\text { Before }\end{array}$ & 0.70 & $\begin{array}{c}\text { Beaver Lower } \\
\text { Before }\end{array}$ & 0.50 \\
\hline $\begin{array}{l}\text { Beaver Lower } \\
\text { Before H03 }\end{array}$ & $\begin{array}{c}\text { Beaver Lower } \\
\text { Before }\end{array}$ & 0.17 & $\begin{array}{c}\text { Beaver Lower } \\
\text { Before }\end{array}$ & 0.47 & $\begin{array}{c}\text { Beaver Lower } \\
\text { Before }\end{array}$ & 0.22 \\
\hline $\begin{array}{l}\text { Beaver Lower } \\
\text { Before H02 }\end{array}$ & $\begin{array}{c}\text { Beaver Lower } \\
\text { Before }\end{array}$ & 0.92 & $\begin{array}{c}\text { Beaver Lower } \\
\text { Before }\end{array}$ & 0.96 & $\begin{array}{c}\text { Beaver Lower } \\
\text { Before }\end{array}$ & 0.83 \\
\hline $\begin{array}{l}\text { Beaver Lower } \\
\text { Before H01 }\end{array}$ & $\begin{array}{c}\text { Beaver Lower } \\
\text { Before }\end{array}$ & 0.63 & $\begin{array}{c}\text { Beaver Lower } \\
\text { Before }\end{array}$ & 0.82 & $\begin{array}{c}\text { Beaver Lower } \\
\text { Before }\end{array}$ & 0.69 \\
\hline $\begin{array}{l}\text { Beaver Lower } \\
\text { Before H00 }\end{array}$ & $\begin{array}{c}\text { Beaver Lower } \\
\text { Before }\end{array}$ & 0.17 & $\begin{array}{c}\text { Beaver Lower } \\
\text { Before }\end{array}$ & 0.47 & $\begin{array}{c}\text { Beaver Lower } \\
\text { Before }\end{array}$ & 0.22 \\
\hline
\end{tabular}


Table 2. Individual assignment of brook trout following culvert replacement at Beaver Creek. Bold letters indicate congruency between all three sampling algorithms used in Geneclass 2.0 (Piry et al. 2002).

\begin{tabular}{|c|c|c|c|c|c|c|}
\hline $\begin{array}{l}\text { Individuals to be } \\
\text { reassigned }\end{array}$ & $\begin{array}{c}\text { Population } \\
\text { Assigned } \\
\text { (Corneut et al. } \\
\text { 1999) }\end{array}$ & Probability & $\begin{array}{c}\text { Population } \\
\text { Assigned } \\
\text { (Petkau et al. 2004) }\end{array}$ & Probability & $\begin{array}{c}\text { Population } \\
\text { Assigned } \\
\text { (Rannala and } \\
\text { Mountain 1997) }\end{array}$ & Probability \\
\hline LowerBeaverOF54 & Black Mid & 0.002 & Dark Run Upper & 0.1 & Buck Up & 0.003 \\
\hline LowerBeaverOF52 & Buck Up & 0.006 & Dark Run Lower & 0.23 & Buck Up & 0.009 \\
\hline LowerBeaverOF60 & $\begin{array}{c}\text { Before Lower } \\
\text { Beaver }\end{array}$ & 0.8 & $\begin{array}{l}\text { Before Lower } \\
\text { Beaver }\end{array}$ & 0.9 & $\begin{array}{c}\text { Before Lower } \\
\text { Beaver }\end{array}$ & 0.83 \\
\hline LowerBeaverOF59 & Black Mid & 0.34 & Spruce Upper & 0.65 & Black Mid & 0.37 \\
\hline LowerBeaverOF55 & Black Mid & 0.1 & Black Mid & 0.31 & Black Mid & 0.14 \\
\hline LowerBeaverOF58 & $\begin{array}{c}\text { Before Lower } \\
\text { Beaver }\end{array}$ & 0.04 & $\begin{array}{c}\text { Before Lower } \\
\text { Beaver }\end{array}$ & 0.26 & $\begin{array}{c}\text { Before Lower } \\
\text { Beaver }\end{array}$ & 0.07 \\
\hline LowerBeaverOF42 & Spruce Lower & 0.06 & Dark Lower & 0.49 & Spruce Lower & 0.08 \\
\hline LowerBeaverOF45 & Upper Rocky & 0.29 & Spruce Upper & 0.7 & Black Mid & 0.32 \\
\hline LowerBeaverOF48 & $\begin{array}{l}\text { Before Lower } \\
\text { Beaver }\end{array}$ & 0.13 & $\begin{array}{c}\text { Before Lower } \\
\text { Beaver }\end{array}$ & 0.42 & $\begin{array}{c}\text { Before Lower } \\
\text { Beaver }\end{array}$ & 0.18 \\
\hline LowerBeaverOF53 & $\begin{array}{c}\text { Before Lower } \\
\text { Beaver }\end{array}$ & 0.6 & $\begin{array}{l}\text { Before Lower } \\
\text { Beaver }\end{array}$ & 0.8 & $\begin{array}{c}\text { Before Lower } \\
\text { Beaver }\end{array}$ & 0.67 \\
\hline LowerBeaverOF46 & Lambert & 0.78 & Lambert & 0.82 & Lambert & 0.83 \\
\hline LowerBeaverOF50 & $\begin{array}{c}\text { Before Lower } \\
\text { Beaver }\end{array}$ & 0.14 & $\begin{array}{c}\text { Before Lower } \\
\text { Beaver }\end{array}$ & 0.43 & $\begin{array}{c}\text { Before Lower } \\
\text { Beaver }\end{array}$ & 0.2 \\
\hline LowerBeaverOF57 & Black Up & 0.47 & Before Lower Beaver & 0.68 & Black Up & 0.52 \\
\hline LowerBeaverOF47 & $\begin{array}{c}\text { Before Lower } \\
\text { Beaver }\end{array}$ & 0.7 & $\begin{array}{c}\text { Before Lower } \\
\text { Beaver }\end{array}$ & 0.86 & $\begin{array}{c}\text { Before Lower } \\
\text { Beaver }\end{array}$ & 0.75 \\
\hline LowerBeaverOF41 & Lambert & 0.88 & Dark Lower & 0.96 & Lambert & 0.92 \\
\hline LowerBeaverOF46II & Black Mid & 0.2 & Black Mid & 0.41 & Black Mid & 0.24 \\
\hline LowerBeaverOF49 & Black Mid & 0.85 & Dark Upper & 0.96 & Black Mid & 0.87 \\
\hline LowerBeaverOF44 & $\begin{array}{c}\text { Before Lower } \\
\text { Beaver }\end{array}$ & 0.45 & $\begin{array}{l}\text { Before Lower } \\
\text { Beaver }\end{array}$ & 0.71 & $\begin{array}{c}\text { Before Lower } \\
\text { Beaver }\end{array}$ & 0.52 \\
\hline
\end{tabular}




\begin{tabular}{|c|c|c|c|c|c|c|}
\hline LowerBeaverOF43 & $\begin{array}{c}\text { Before Lower } \\
\text { Beaver }\end{array}$ & 0.86 & $\begin{array}{c}\text { Before Lower } \\
\text { Beaver }\end{array}$ & 0.93 & $\begin{array}{c}\text { Before Lower } \\
\text { Beaver }\end{array}$ & 0.89 \\
\hline LowerBeaverOF92 & Black Up & 0.85 & Spruce Upper & 0.94 & Black Up & 0.89 \\
\hline UpperBeaverOF86 & Black Mid & 0.78 & Dark Upper & 0.88 & Black Mid & 0.8 \\
\hline UpperBeaverOF90 & $\begin{array}{c}\text { Before Lower } \\
\text { Beaver }\end{array}$ & 0.91 & $\begin{array}{c}\text { Before Lower } \\
\text { Beaver }\end{array}$ & 0.94 & $\begin{array}{c}\text { Before Lower } \\
\text { Beaver }\end{array}$ & 0.9 \\
\hline UpperBeaverOF84 & Black Mid & 0.72 & Spruce Upper & 0.99 & Black Mid & 0.94 \\
\hline UpperBeaverOF81 & $\begin{array}{l}\text { Before Upper } \\
\text { Beaver }\end{array}$ & 0.5 & $\begin{array}{l}\text { Before Upper } \\
\text { Beaver }\end{array}$ & 0.76 & $\begin{array}{c}\text { Before Lower } \\
\text { Beaver }\end{array}$ & 0.62 \\
\hline UpperBeaverOF82 & $\begin{array}{c}\text { Before Lower } \\
\text { Beaver }\end{array}$ & 0.005 & Before Upper Beaver & 0.14 & Before Lower Beaver & 0.015 \\
\hline UpperBeaverOF99 & $\begin{array}{c}\text { Before Lower } \\
\text { Beaver }\end{array}$ & 0.27 & $\begin{array}{c}\text { Before Lower } \\
\text { Beaver }\end{array}$ & 0.58 & $\begin{array}{c}\text { Before Lower } \\
\text { Beaver }\end{array}$ & 0.35 \\
\hline UpperBeaverOF91 & $\begin{array}{c}\text { Before Lower } \\
\text { Beaver }\end{array}$ & 0.35 & $\begin{array}{c}\text { Before Lower } \\
\text { Beaver }\end{array}$ & 0.64 & $\begin{array}{c}\text { Before Lower } \\
\text { Beaver }\end{array}$ & 0.43 \\
\hline UpperBeaverOF88 & Black Mid & 0.88 & Before Lower Beaver & 0.92 & Black Mid & 0.9 \\
\hline UpperBeaverOF96 & Black Mid & 0.04 & Black Mid & 0.21 & Black Mid & 0.06 \\
\hline UpperBeaverOF95 & $\begin{array}{c}\text { Before Lower } \\
\text { Beaver }\end{array}$ & 0.05 & $\begin{array}{c}\text { Before Lower } \\
\text { Beaver }\end{array}$ & 0.26 & $\begin{array}{c}\text { Before Lower } \\
\text { Beaver }\end{array}$ & 0.07 \\
\hline UpperBeaverOF89 & Black Mid & 0.38 & Black Mid & 0.56 & Black Mid & 0.42 \\
\hline UpperBeaverOF98 & $\begin{array}{c}\text { Before Lower } \\
\text { Beaver }\end{array}$ & 0.19 & $\begin{array}{l}\text { Before Lower } \\
\text { Beaver }\end{array}$ & 0.5 & $\begin{array}{l}\text { Before Lower } \\
\text { Beaver }\end{array}$ & 0.27 \\
\hline UpperBeaverOF97 & $\begin{array}{c}\text { Before Upper } \\
\text { Beaver }\end{array}$ & 0.02 & $\begin{array}{c}\text { Before Upper } \\
\text { Beaver }\end{array}$ & 0.37 & $\begin{array}{c}\text { Before Upper } \\
\text { Beaver }\end{array}$ & 0.046 \\
\hline UpperBeaverOF87 & $\begin{array}{c}\text { Before Lower } \\
\text { Beaver }\end{array}$ & 0.37 & $\begin{array}{c}\text { Before Lower } \\
\text { Beaver }\end{array}$ & 0.66 & $\begin{array}{c}\text { Before Lower } \\
\text { Beaver }\end{array}$ & 0.45 \\
\hline UpperBeaverOF94 & $\begin{array}{l}\text { Before Upper } \\
\text { Beaver }\end{array}$ & 0.1 & $\begin{array}{c}\text { Before Upper } \\
\text { Beaver }\end{array}$ & 0.53 & $\begin{array}{c}\text { Before Upper } \\
\text { Beaver }\end{array}$ & 0.19 \\
\hline UpperBeaverOF83 & Black Mid & 0.35 & Dark Upper & 0.65 & Black Mid & 0.4 \\
\hline UpperBeaverRI100 & Buck Up & 0.49 & Dark Lower & 0.85 & Buck Up & 0.51 \\
\hline UpperBeaverOF93 & $\begin{array}{c}\text { Before Lower } \\
\text { Beaver }\end{array}$ & 0.71 & $\begin{array}{c}\text { Before Lower } \\
\text { Beaver }\end{array}$ & 0.86 & $\begin{array}{c}\text { Before Lower } \\
\text { Beaver }\end{array}$ & 0.76 \\
\hline
\end{tabular}


Figure 1. Map of the Upper Shavers Fork watershed, eastern West Virginia. Location of sampling is indicated by the corresponding number of samples.

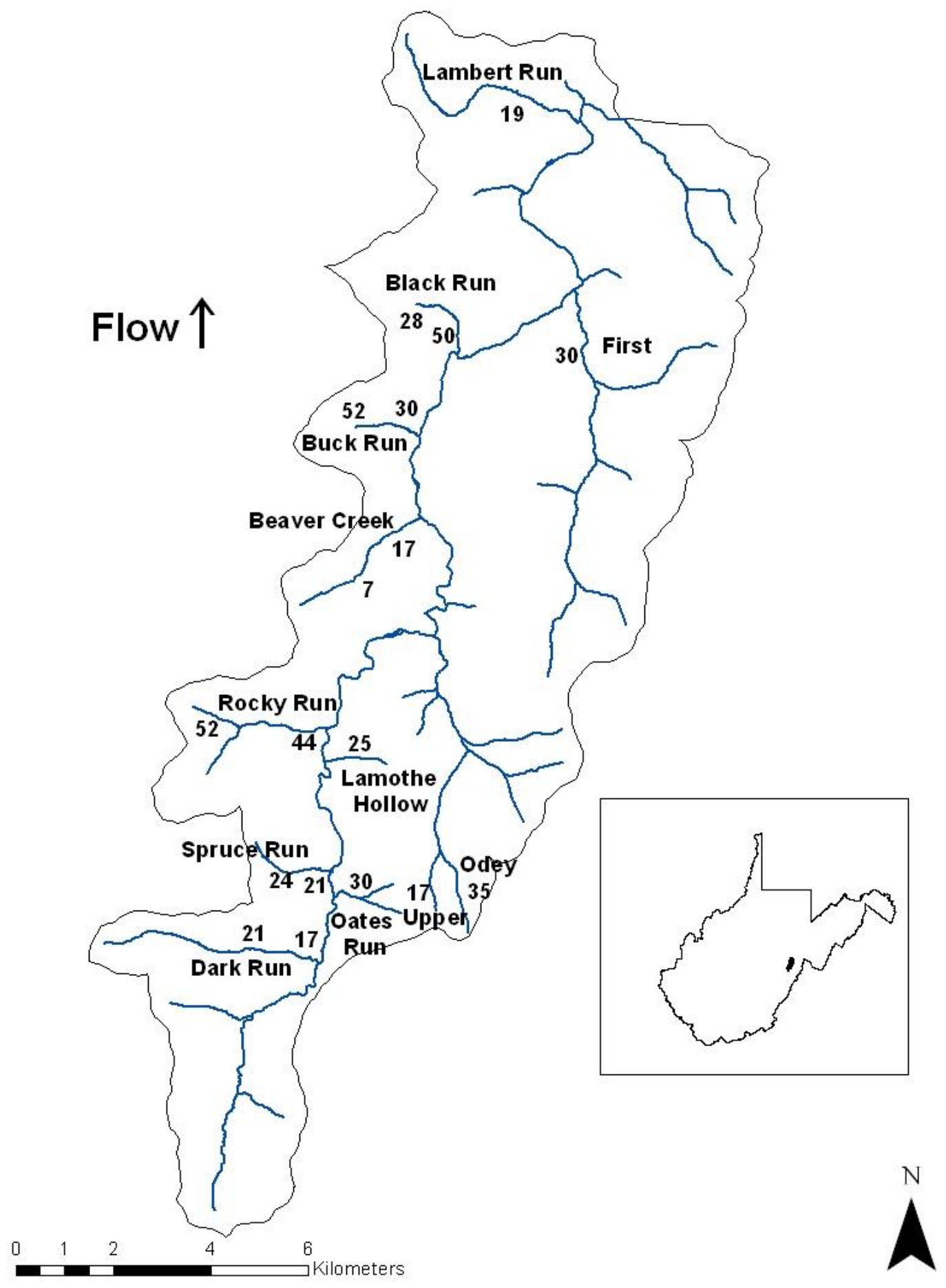


Figure 2. Natural log of likelihood plotted against the number of possible populations $K$, generated in STRUCTURE HARVESTER (Earl and vonHoldt, 2012). The length of bars indicates the variability at a given population size.

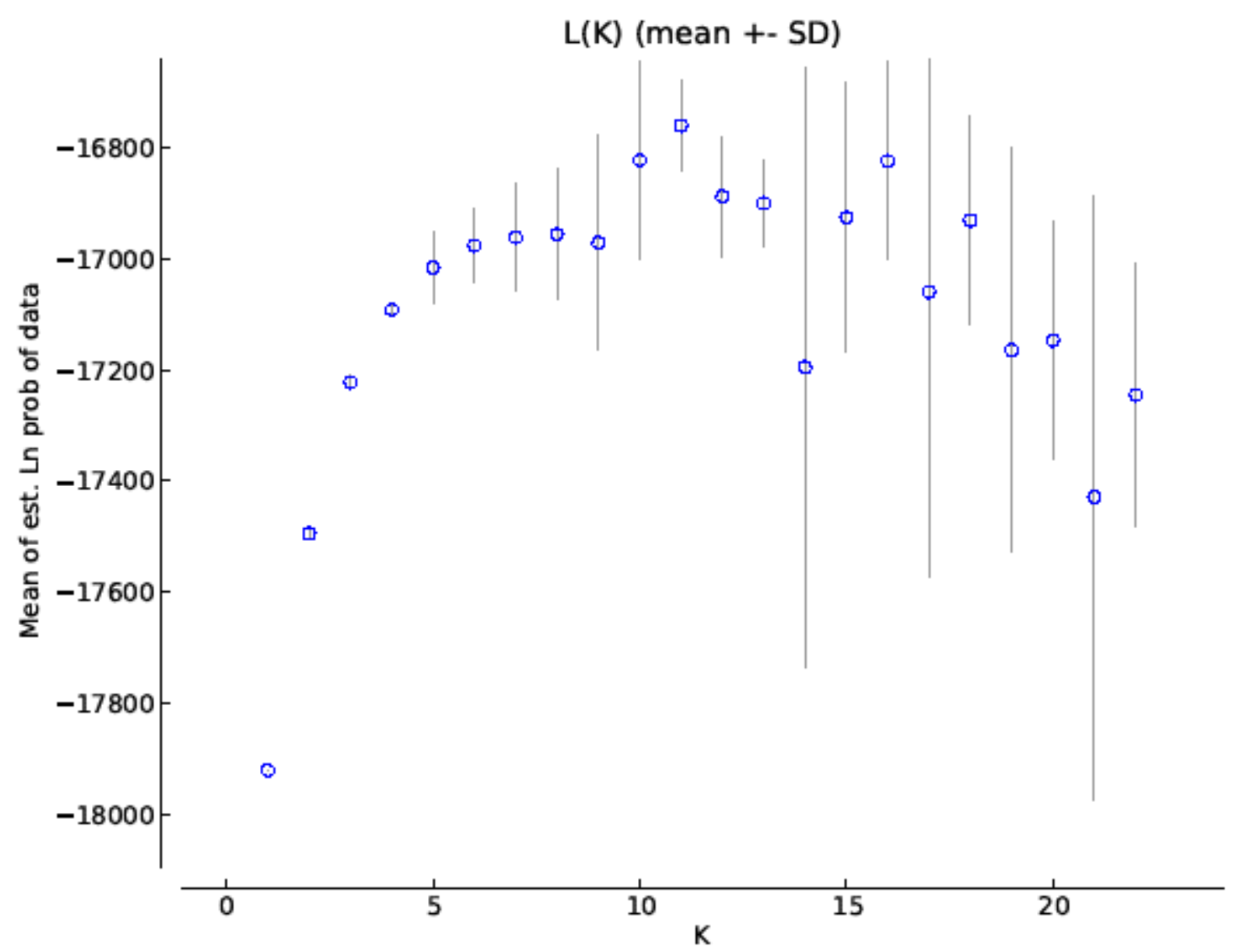


Figure 3. Number of populations indicated by $\Delta K$ plot generated in STRUCTURE HARVESTER (Earl and vonHoldt, 2012). A strong peak at $\Delta K=2$ indicates two possible populations.

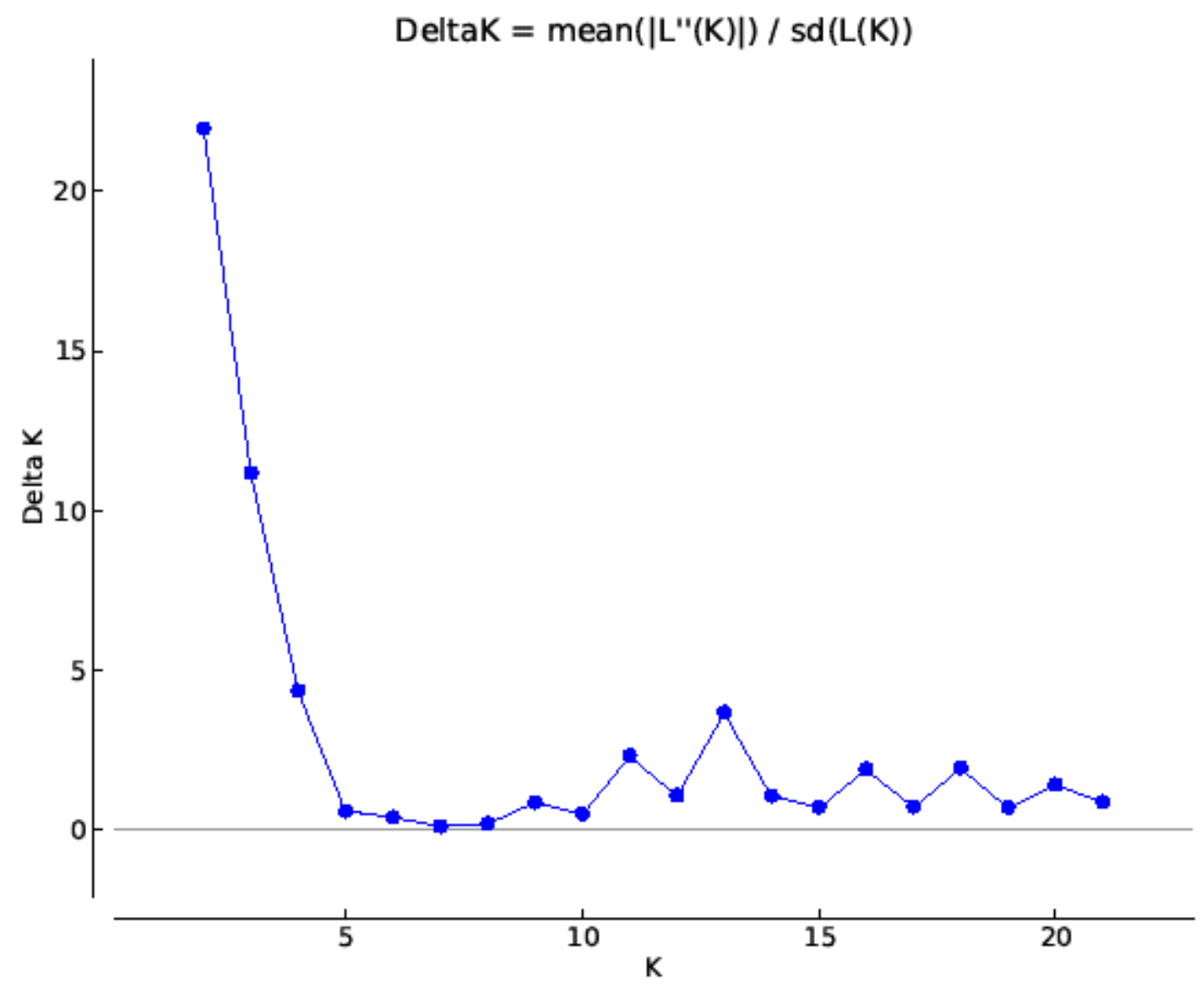


Figure 4. STRUCTURE plot after 100,000 MCMC using sampling locations as known priors, $K=2$, where $1=\mathrm{Buck}$ Up, $2=\mathrm{Buck}$ Mid, 3=Oates Run, 4=Black Upper, 5=Black Middle, 6=Upper Beaver After Replacement, 7=Lower Beaver After Replacement, 8=Lamothe Hollow, 9=Upper Rocky, 10=Lower Rocky, 11=Spruce Lower, 12=Spruce Upper, 13=Dark Lower, 14=Dark Upper, 15=Upper Beaver Before Replacement, 16=Lower Beaver Before Replacement, 17=Lambert Run, 18=First, 19=Odey, 20=Upper.

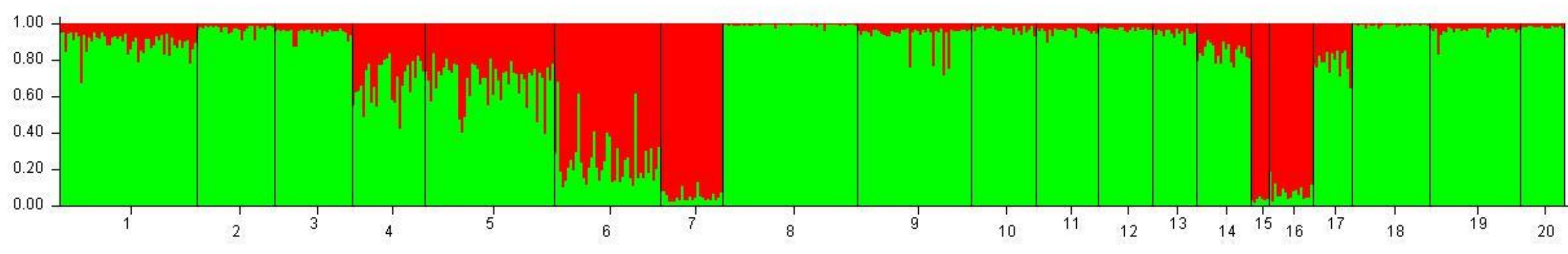

